Western University

Scholarship@Western

Civil and Environmental Engineering

Civil and Environmental Engineering

Publications

Department

2016

Seismic performance of steel moment resisting frames utilizing superelastic shape memory alloys

\author{
Papia Sultana \\ Western University \\ Maged A. Youssef \\ Western University, youssef@uwo.ca
}

Follow this and additional works at: https://ir.lib.uwo.ca/civilpub

Part of the Civil and Environmental Engineering Commons

Citation of this paper:

Sultana, Papia and Youssef, Maged A., "Seismic performance of steel moment resisting frames utilizing superelastic shape memory alloys" (2016). Civil and Environmental Engineering Publications. 196.

https://ir.lib.uwo.ca/civilpub/196 


\title{
Seismic Performance of Steel Moment Resisting Frames Utilizing Superelastic Shape Memory Alloys
}

\author{
Papia Sultana ${ }^{\mathrm{a}}$, Maged A. Youssef ${ }^{\mathrm{b}}$
}

\begin{abstract}
Steel structures dissipate the seismic energy through steel yielding, which results in residual deformations. Although conventional earthquake-resisting structural systems provide adequate seismic safety, they experience significant structural damage when exposed to strong ground shaking. Seismic residual drifts complicate the repair of damaged structures or render the structure as irreparable. Therefore, systems that can minimize the seismic residual deformations are needed. Superelastic shape memory alloys (SMAs) have the ability to undergo large deformations and recover all plastic deformations upon unloading. Their utilization in steel structures can significantly reduce seismic residual deformations, which will facilitate postseismic retrofitting. Although the literature provides few research data on using SMA in steel beam-column connections, previous research did not address their optimum use. This paper identifies the required locations of SMA connections in a typical steel moment resisting frame to enhance its seismic performance in terms of maximum inter-storey drift, residual deformations, and damage scheme.
\end{abstract}

Keywords: Steel moment resisting frame, Shape memory alloy, Inter-storey drift, Residual drift, Seismic performance, Dynamic analysis.

a PhD Candidate, Western University, Civil and Environmental Engineering, London, ON, Canada N6A 5B9, Email: psultana@uwo.ca.

${ }^{\mathrm{b}}$ Corresponding Author, Professor, Western University, Civil and Environmental Engineering, London, ON, Canada N6A 5B9, Email: youssef@uwo.ca, Tel.: 519-661-2111 Ext. 88661. 


\subsection{INTRODUCTION}

Structural steel is widely used in moment resisting frames of mid- and high-rise buildings. Modern code provisions categorize buildings according to their configurations, structural systems, materials and construction details [1-3]. A structure is assumed to behave in a ductile manner if it can experience large inelastic deformations without significant degradation in strength. Steel moment resisting frames are one of the popular seismic load resistance systems because of their ductility. During a seismic event, they are expected to experience large inelastic deformations, while maintaining the life safety level for the occupants. Plastic hinges are expected to form in the beams, which may exhibit large yielding deformations leading to localized damage in the floor slabs and columns. Those yielding deformations are not recovered after the seismic event, which results in permanent residual deformations.

Researchers are innovating to find design solutions that minimize the seismic residual deformations. Special post-tensioned partially restrained connections were designed to provide recentering capability after a seismic event [4-6]. Shape memory alloys (SMAs) had also widely attracted the attention of researchers in recent years because of their self-centering capability as well as energy dissipation features. Nickel Titanium (NiTi) SMAs were the most researched [7]. The two fundamental and characteristic properties of SMA are: shape memory effect (SME) and superelasticity (SE). SME is the ability of the material to recover from large mechanically-induced strains via moderate increase in its temperature. SE is the ability of the material to support relatively high inelastic strains and return to its original shape upon load removal.

Ocel et al. [8] tested an external beam-column connection that utilized martensite SMA rods. The connection showed high energy dissipation, large ductility and no strength degradation up to $4 \%$ drift level. The connection was also able to recover $76 \%$ of the experienced drift when the SMA 
tendons were heated. Ma et al. [9] investigated the behaviour of extended end-plate connections consisting of long shank Nitinol superelastic SMA bolts, continuity plates, beam flange ribs and web stiffeners using a 3D finite element model. The connections experienced cyclic elongations of the SMA bolts, however the traditional beam local buckling was avoided. The deformations of the SMA bolts were recoverable upon unloading. Ma et al. [10] conducted a quasi-static test of an extended end-plate connection utilizing long shank SMA bolts. The connection exhibited high deformation capacity with maximum inter-storey drift (MID) angle beyond 0.02 rad. Sepúlveda et al. [11] tested a connection that utilized $3 \mathrm{~mm}$-diameter copper-based (CuAlBe) SMA bars. The proposed connection experienced self-centering behaviour, dissipated moderate amount of energy, and showed no strength degradation up to 3\% drift ratio. Speicher et al. [12] tested four half-scale interior beam-column connections that utilized steel tendons, superelastic NiTi SMA tendons, martensitic NiTi SMA tendon, or combination of superelastic NiTi tendons and aluminum tendons. The superelastic NiTi SMA connection showed significant recentering capability, recovering a large portion of the post-elastic drift compared to the other three connections. DesRoches et al. [13] studied the seismic performance of steel moment resisting frames with SMA bars at the beam to column connections. Two steel frames were selected: low rise (three-storey) frame and medium rise (nine-storey) frame. All the beam-column connections were assumed to utilize SMA bars. Nonlinear time history analyses showed that martensitic SMA connections are most effective in controlling MID demands whereas superelastic SMA connections are more effective in controlling maximum residual inter-storey drift (MRID) demands. Further, probabilistic seismic demand assessment (PSDA) was performed by Ellingwood et al. [14]. The hazard curves showed that the benefits of incorporating SMA connections depend on the seismic demand level. Researchers had also investigated the seismic performance of steel and RC frames equipped with SMA braces [15- 
17]. The conventional steel bracing system has limited ductility and energy dissipation due to buckling of the braces, and their asymmetric behavior [18]. McCormic et al. [17] assessed the performance of steel braced frames equipped with superelastic SMA braces. The MRID was limited following an earthquake due to the recentering capability of the braces. Kari et al. [19] conducted a numerical study to investigate the benefit of using combination of buckling restrained braces and SMA braces for new designs as well as retrofitting purposes. Results revealed that, with the proper configuration, residual and inter-storey drifts can be minimized. Antonio et al. [20] conducted shake table tests to assess the effectiveness of seven different passive and semi-active energy dissipating braces (EDBs). It was concluded that EDBs consisting of both SMA and viscoelastic damping material lead to recentering of the gravity load resisting system at the end of a seismic event with the added advantage of higher energy dissipation because of the visco-elastic material. Miller [21] investigated the seismic behavior and performance of self-centering bucklingrestrained braces (SC-BRBs) that utilized SMAs. The SC-BRBs consisted of a typical BRB component, which provides energy dissipation, and pre-tensioned superelastic NiTi SMA rods, which provide self-centering. The SMA rods were attached to the BRB portion of the brace using a set of concentric tubes and free-floating anchorage plates that caused the SMA rods to elongate when the brace is either in tension and compression. Two half-scale SC-BRB specimens were fabricated and subjected to quasi static cyclic loading. The specimens exhibited a stable, flagshaped hysteretic response. The study concluded that proper SMA pretension force and BRB core yield force are imperative to achieve full self-centering of the bracing.

As SMAs are very expensive, studies are required to optimize their use in the steel frames. Although the literature provides few research data on using SMA in steel beam-column connections and bracing elements of steel frames, further research is necessary regarding their 
optimum use. This study examines the possibility of maintaining the benefit of reduced residual inter-storey drift (RID) using SMA connections at selected parts of the frame and, thus, reducing the associated costs. The objective of this paper is to identify the required locations of the SMA connections in a typical steel moment resisting frame to optimize its seismic performance in terms of inter-storey drift, residual deformations and damage scheme.

The paper starts by providing details about the examined steel frame and the modeling assumptions. The simplified method proposed by Sultana and Youssef [22] as well as incremental dynamic analysis (IDA) were then used to identify the floors that are expected to experience sever damage during seismic excitations. The frame was redesigned to incorporate SMA in the critical joints. Six different potential designs were examined using nonlinear dynamic analyses. Their seismic performance as compared to the steel frame allowed selecting the frame that has the best seismic performance in terms of maximum inter-storey drift (MID), maximum residual interstorey drift (MRID) and damage distribution.

\subsection{STEEL MOMENT FRAME CHARACTERSITICS AND MODELING}

A ten storey building is selected as a case study. The frame (Figure 1) is designed by Ozhendekci et al. [23] according to Turkish standards, which is similar to AISC 316-89 [24]. As the structure is symmetric, a two-dimensional (2D) model of the steel moment resisting frame (SMRF) is developed using the software SeismoStruct [25]. This software is based on the fibre element approach. Beams and columns are divided into four and two displacement based inelastic frame elements, respectively. The distributed dead and live loads are converted to equivalent point loads and applied at the two end nodes of each beam element. The mass of the building is converted into lumped masses that are assumed to be located at the two ends of each beam element. The panel 
zone is modeled using rigid elements. Bilinear material behaviour with $3 \%$ strain hardening is considered using the distributed plasticity approach. The P- $\Delta$ effect is included in the analysis. Validation of this modeling technique was conducted by Sultana and Youssef [22]. Local failure of beams and columns are assumed to be associated with an ultimate chord rotation $\left(\theta_{\mathrm{u}}\right)[26]$.

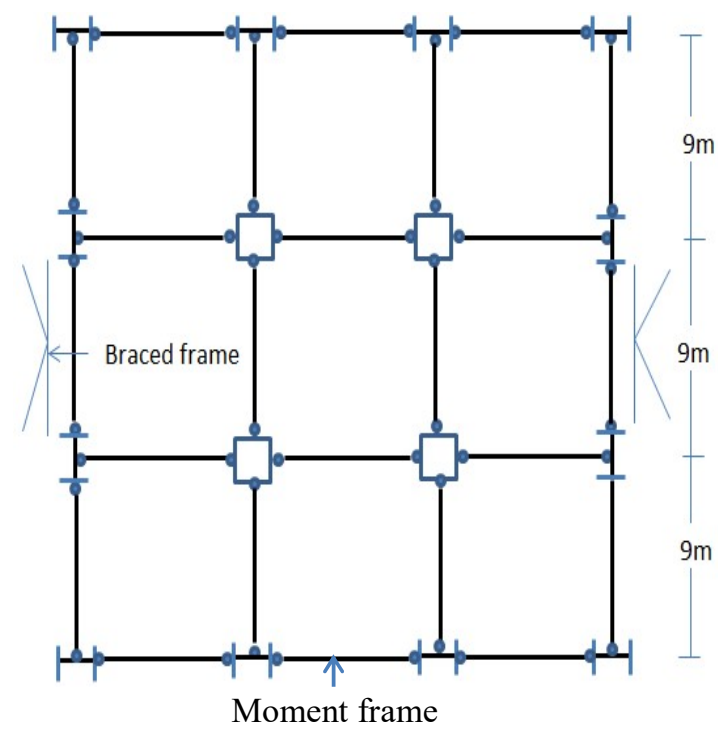

(a) Plan view

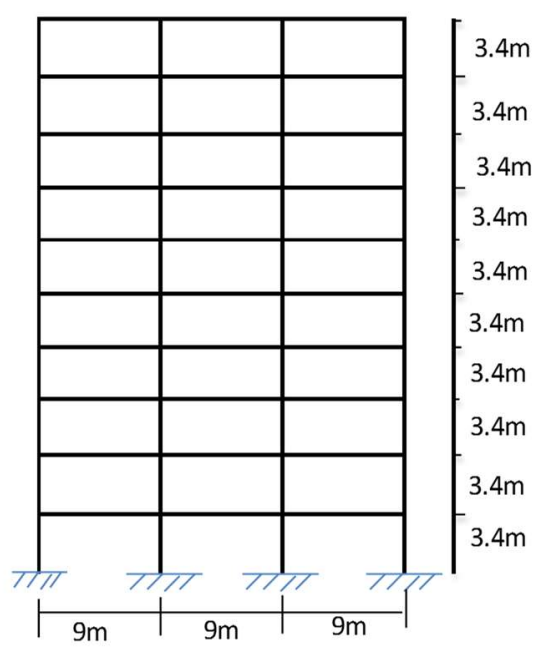

(b) Elevation of typical moment frame

Figure 1: 10-storey building [23]

\subsection{PREDICTION OF THE SEVERELY DAMAGED FLOOR}

Sultana and Youssef [22] proposed a simplified method to identify the critical storey of a SMRF based on pushover analysis. The method allows evaluating the failure inter-storey drift (FID) limits for each storey. These limits for the considered ten storey SMRF are given in the Table 1. The first storey is clearly the severely damaged storey as the limiting ID $(2.38 \%)$ of this storey is the lowest followed by the $5^{\text {th }}$ storey $(27.7 \%)$. 
Table 1: Limiting FID (\%) for different floors of the 10 storey frame

\begin{tabular}{|c|c|c|c|c|c|c|c|c|c|c|}
\hline Storey & 1 & 2 & 3 & 4 & 5 & 6 & 7 & 8 & 9 & 10 \\
\hline $\begin{array}{c}\text { Proposed } \\
\text { FID (\%) }\end{array}$ & 2.38 & 31.1 & 28.6 & 29.4 & 27.7 & 30.7 & 37.9 & 29.9 & 31.2 & 50.6 \\
\hline
\end{tabular}

\subsection{DYNAMIC ANALYSIS OF THE SMRF}

Eigen value analysis was performed to determine the natural period of vibrations and mode shapes.

The first and second fundamental horizontal periods of vibrations are $2.21 \mathrm{sec}$. and $0.78 \mathrm{sec}$, respectively. The behaviour of this frame was dominated mainly by the first mode with some sensitivity to higher modes.

Incremental dynamic analysis (IDA), developed by Luco and Cornell [27], was performed to assess the seismic performance of the frame, and, thus identify the location of the severely damaged beams and columns. This analysis requires a series of nonlinear dynamic analyses considering different intensity levels for the ground motion to cover the behaviour of the frame during the elastic, yielding, and collapse or dynamic instability stages. Five different ground motions, obtained from PEER ground motion database [28], were selected to conduct the incremental dynamic analysis (IDA). Characteristics of the selected ground motions are listed in Table 2. Figure 2 shows the elastic response spectra for 5\% damping of these selected ground motions. IDA analysis was terminated when one of the columns reaches the limiting rotation proposed by FEMA356.

Table 3 shows the 5\% damped spectral acceleration at collapse at the structure's first mode period [ $\left.\mathrm{S}_{\mathrm{a}}(\mathrm{T} 1,5 \%)\right]$, MID and MRID of the steel frame considering the five ground motions. Values of 
the MID varied from $2.75 \%$ to $5.02 \%$ and the MRID varied from $0.29 \%$ to $1.21 \%$. The damage schemes at collapse are shown in the Figure 3.

Table 2: Characteristics of ground motions

\begin{tabular}{|l|c|c|l|c|}
\hline \multicolumn{1}{|c|}{ Earthquake } & $\begin{array}{c}\text { Date } \\
\mathrm{m} / \mathrm{d} / \mathrm{yr}\end{array}$ & $\begin{array}{c}\text { Ms } \\
\text { magnitude }\end{array}$ & \multicolumn{1}{|c|}{ Station } & PGA( g) \\
\hline Northridge & $01 / 17 / 1994$ & 6.7 & Arleta-Nordhoff & 0.344 \\
\hline Imperial Valley & $10 / 15 / 1979$ & 6.9 & El Centro Array \#6 & 0.439 \\
\hline Loma Prieta & $10 / 18 / 1989$ & 7.1 & Capitola & 0.529 \\
\hline Tabas & $09 / 16 / 1978$ & 6.9 & Tabas & 0.852 \\
\hline San Fernando & $02 / 02 / 1971$ & 6.6 & Pacoima dam & 1.23 \\
\hline
\end{tabular}

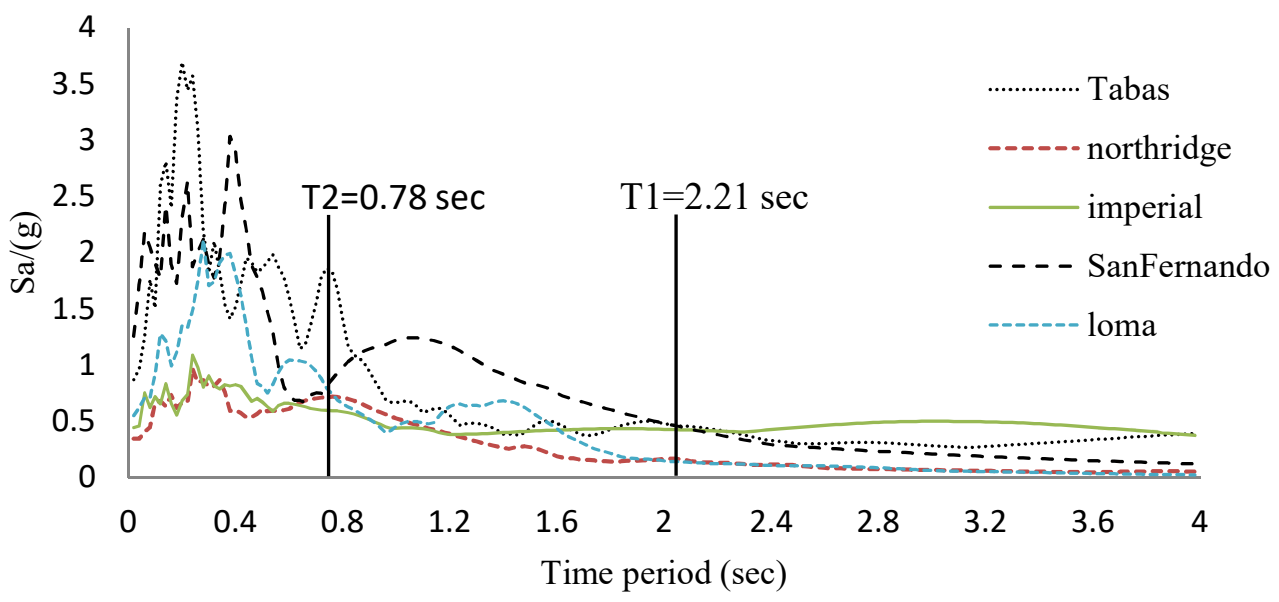

Figure 2: Elastic response spectral acceleration for horizontal seismic component

Table 3 MID and MRID of steel frame (Frame 1)

\begin{tabular}{|l|l|l|r|}
\hline Ground motion & Sa(T1,5\%) & \multicolumn{2}{|c|}{ Frame 1 } \\
\cline { 3 - 4 } & at collapse & MID (\%) & MRID (\%) \\
\hline
\end{tabular}




\begin{tabular}{|c|c|c|c|} 
Imperial & $(0.341 \mathrm{~g})$ & $2.97\left(2^{\text {nd }}\right.$ storey $)$ & $0.67\left(2^{\text {nd }}\right.$ floor $)$ \\
\hline Northridge & $(0.489 \mathrm{~g})$ & $3.17\left(3^{\text {rd }}\right.$ storey $)$ & $0.41\left(1^{\text {st }}\right.$ floor $)$ \\
\hline Loma & $(0.619 \mathrm{~g})$ & $5.02\left(7^{\text {th }}\right.$ storey $)$ & $0.56\left(8^{\text {th }}\right.$ storey $)$ \\
\hline San Fernando & $(0.476 \mathrm{~g})$ & $3.48\left(6^{\text {th }}\right.$ storey $)$ & $1.21\left(4^{\text {th }}\right.$ storey $)$ \\
\hline Tabas & $(0.445 \mathrm{~g})$ & $2.75\left(3^{\text {rd }}\right.$ storey $)$ & $0.29\left(2^{\text {nd }}\right.$ storey $)$ \\
\hline
\end{tabular}

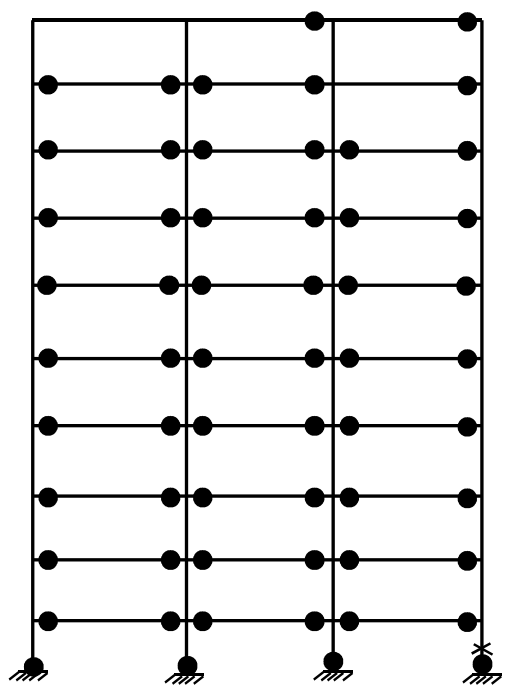

Imperial $[\mathrm{Sa}(\mathrm{T} 1,5 \%)=0.341 \mathrm{~g}]$

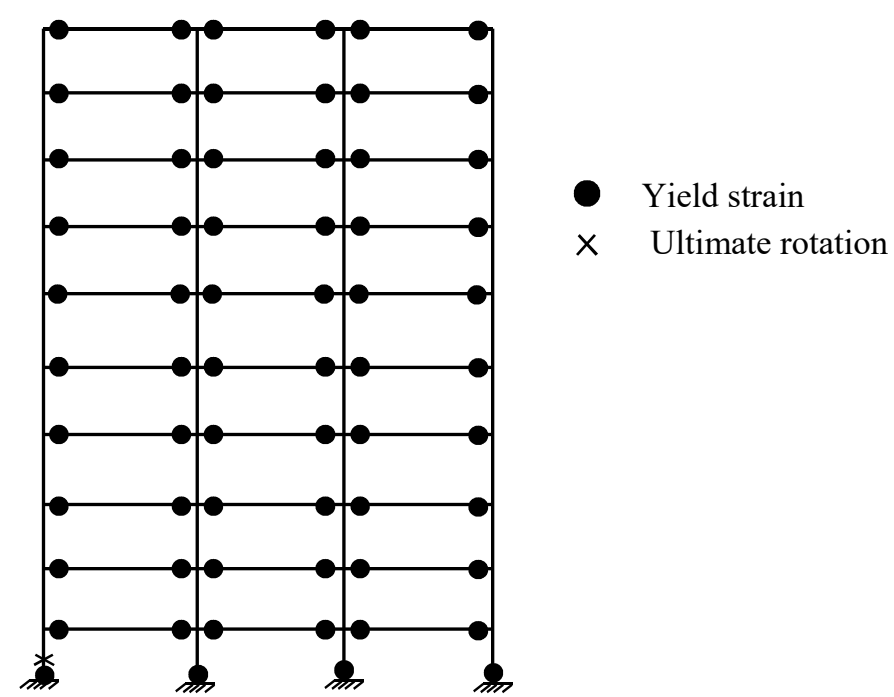

San Fernando $[\mathrm{Sa}(\mathrm{T} 1,5 \%)=0.476])$

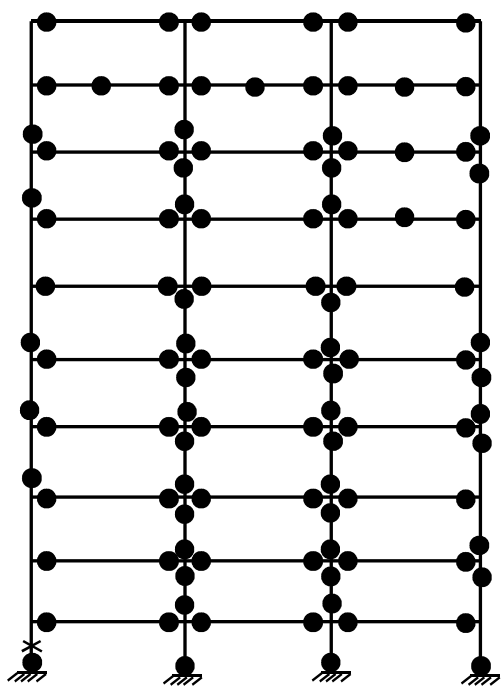

Loma $[\mathrm{Sa}(\mathrm{T} 1,5 \%)=0.619])$

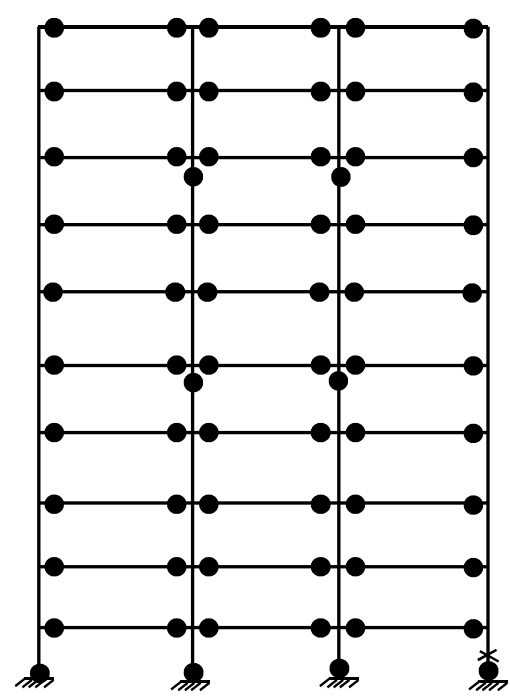

Northridge $[\mathrm{Sa}(\mathrm{T} 1,5 \%)=0.489 \mathrm{~g}]$

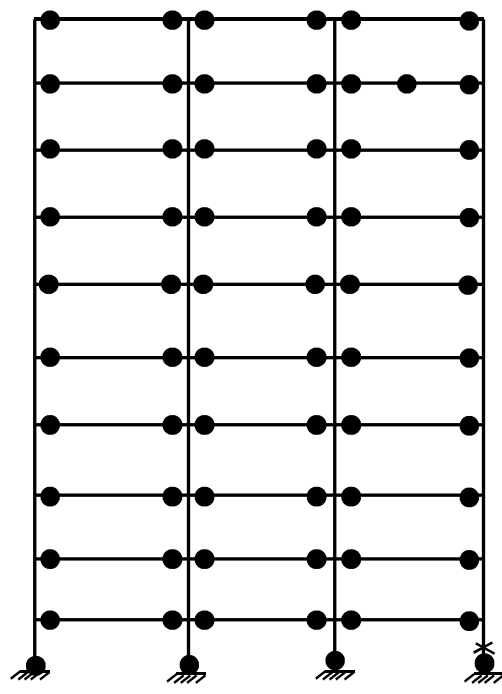

Tabas $[\mathrm{Sa}(\mathrm{T} 1,5 \%)=0.445 \mathrm{~g}]$

The columns and majority of the beams of the first floor have yielded considering all ground motions. Loma earth Figure 3: Damage distribution of the steel frame (Frame 1)

ding can also be observed at mid-spans of the $7^{\text {th }}, 8^{\text {th }}$, and $9^{\text {th }}$ floor beams. For all of the considered 
seismic excitations, one of the first floor columns has reached the ultimate rotation, which is considered as frame failure in this paper. The MID and MRID have not occurred at the first floor although it is the most damaged floor. The ID of the first floor varied from $1.90 \%$ to $2.17 \%$ for the considered ground motions.

\subsection{SMA- STEEL FRAME CHARACTERISTICS AND MODELING}

The analyzed SMRF was redesigned using combination of rigid and SMA connections. According to the simplified method the columns of the $1^{\text {st }}$ and the $5^{\text {th }}$ storeys can be considered critical as the FID limits are the lowest, which suggests that potential locations for SMA joints are in the $1^{\text {st }}, 4^{\text {th }}$, and $5^{\text {th }}$ stories. The damage distributions obtained from dynamic analyses showed failure of a $1^{\text {st }}$ storey column along with yielding of the columns in the $4^{\text {th }}-6^{\text {th }}$ and $8^{\text {th }}-9^{\text {th }}$ stories as well as severe yielding of the beams in the $9^{\text {th }}$ storey. Based on the above observations, the six different designs, shown in Figure 4, were selected to capture potential locations for SMA connections. The SMA connections were assumed to have similar details as the joint tested by Speicher et al. [12]. In the design phase, the moment capacity of the SMA connections were set equal to $80 \%$ of the plastic moment capacity of the connecting beams to force inelastic deformations to occur in the SMA bars. The area of the SMA bars ( $\left.\mathrm{A}_{\mathrm{SMA}}\right)$ is, thus, calculated using equation 1.

$\mathrm{A}_{\mathrm{SMA}}=0.8 \mathrm{M}_{\mathrm{pb}} / \mathrm{dF}_{\mathrm{Y}(\mathrm{SMA})}$

Where, $\mathrm{M}_{\mathrm{pb}}$ is the plastic moment capacity of the connecting beam, $\mathrm{d}$ is the distance between the top and the bottom SMA bars, and $\mathrm{F}_{\mathrm{y}(\mathrm{SMA})}$ is the stress at which SMA state changes from the austenite to stress-induced martensite. 


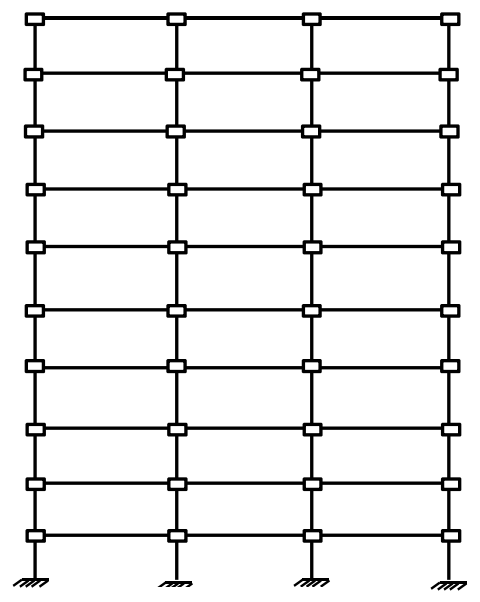

Frame 2

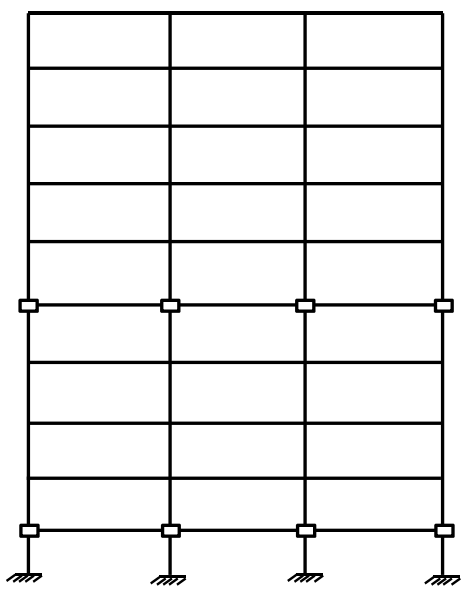

Frame 5

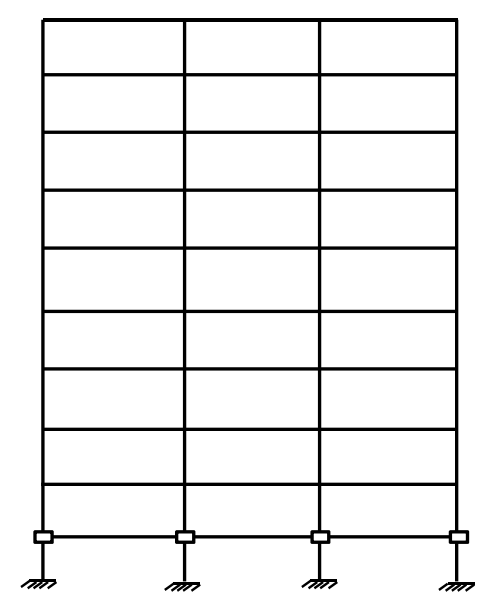

Frame 3

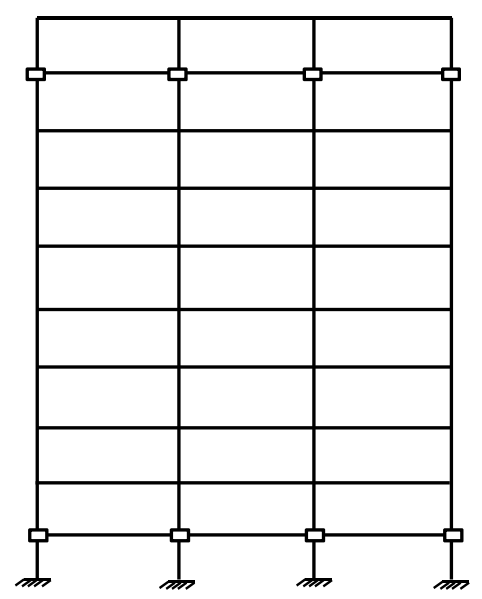

Frame 6

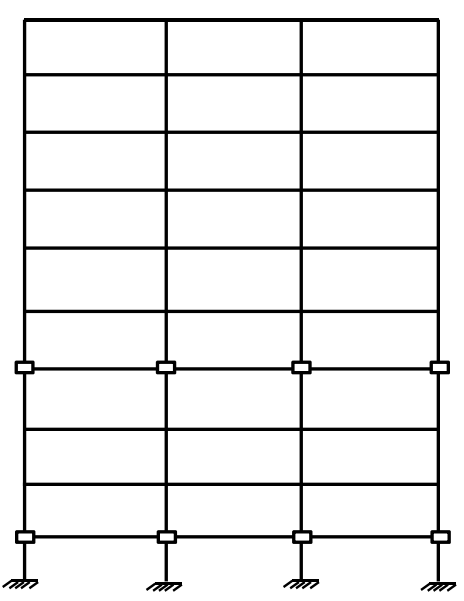

Frame 4

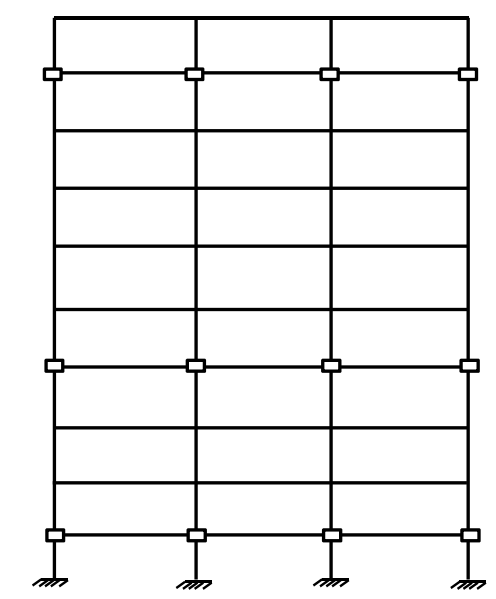

Frame 7

Figure 4: Location of SMA connections

\subsection{SMA connections}

Two different SMA connections were modeled in SeismoStruct to validate the modeling technique. Figure 5 shows the FE model of the SMA connection that was tested by Speicher et al. [12]. The slotted shear tab allows for the relative rotation between the beam and the column. A special modeling technique was utilized to model this connection that involves: (1) modeling the SMA bars using inelastic truss elements, (2) capturing the superelastic behaviour using the uniaxial material model that follows the constitutive relationship proposed by Auricchio and Sacco [29], (3) modeling the beams and columns using displacement based inelastic frame elements, and 
(4) allowing for relative rotation between the beam and column elements using hinges that were modelled using zero length link elements, as shown in the Figure 5(b). A martensite SMA connection, which was tested by Ocel et al. [8], was also modeled. A different modeling technique was utilized for this connection, where the SMA bars were modelled using zero length link elements as shown in Figure 6. The force-displacement response curves for those link elements were derived from the stress-strain behaviour of the SMA material. Good agreements between the experimental and simulated moment-rotation responses were achieved for both connections as shown in Figures 7 and 8. The proposed connection models were found to be capable of predicting the moment-rotation responses, energy dissipation, and residual deformations with adequate accuracy. 


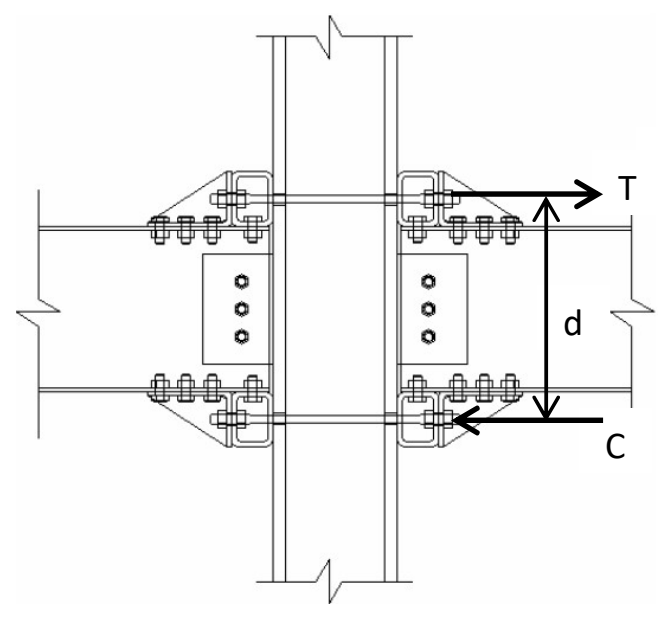

a) SMA connection [12]

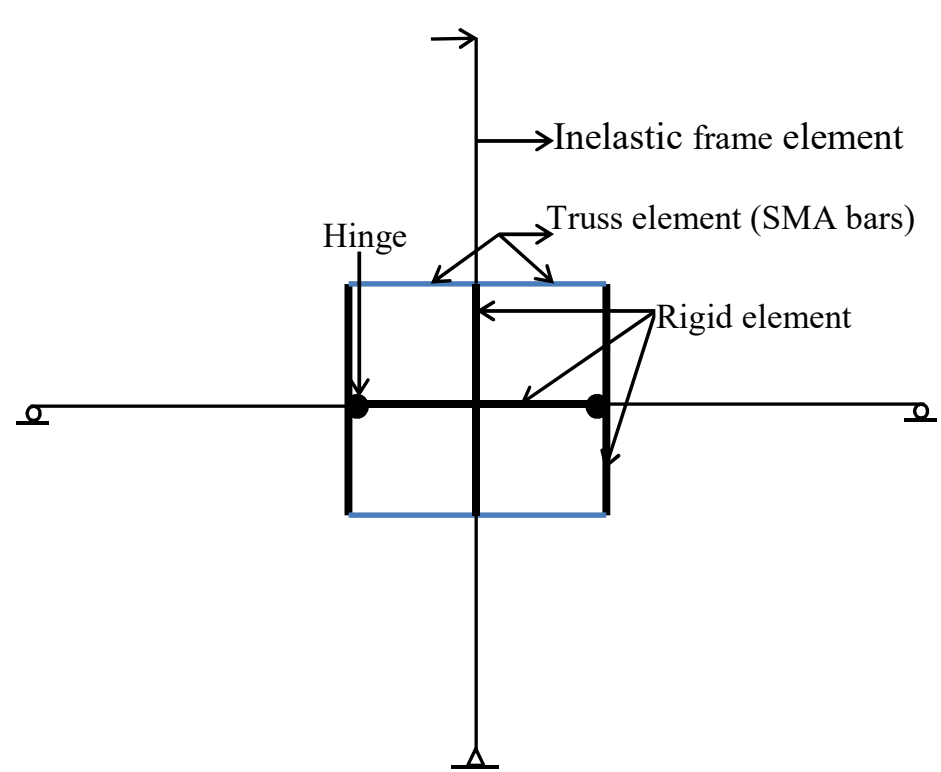

b) FE model

Figure 5: Finite element model of superelastic SMA connection

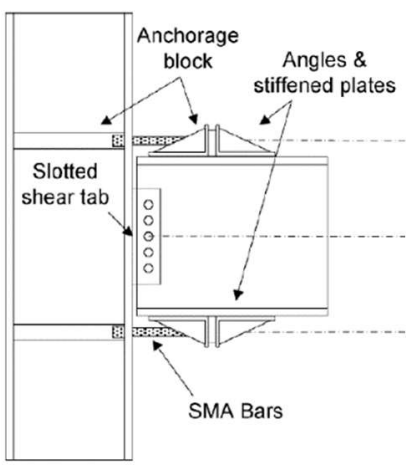

a) SMA connection [8]

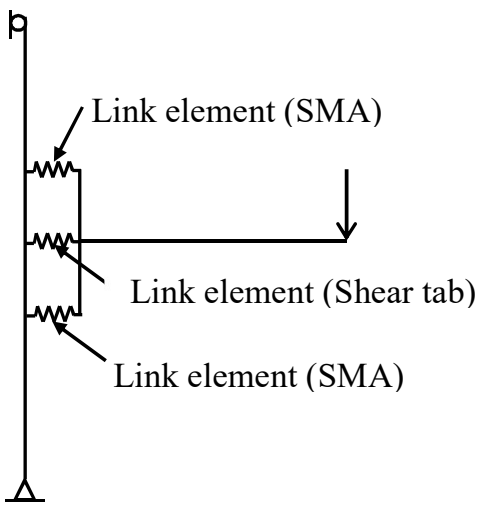

b) FE model

Figure 6: Finite element model of martensite SMA connection 


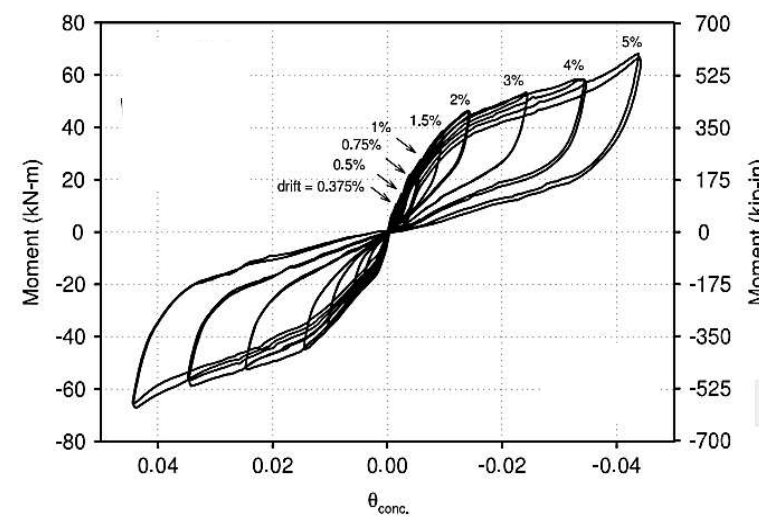

a) Experimental moment-rotation [12]

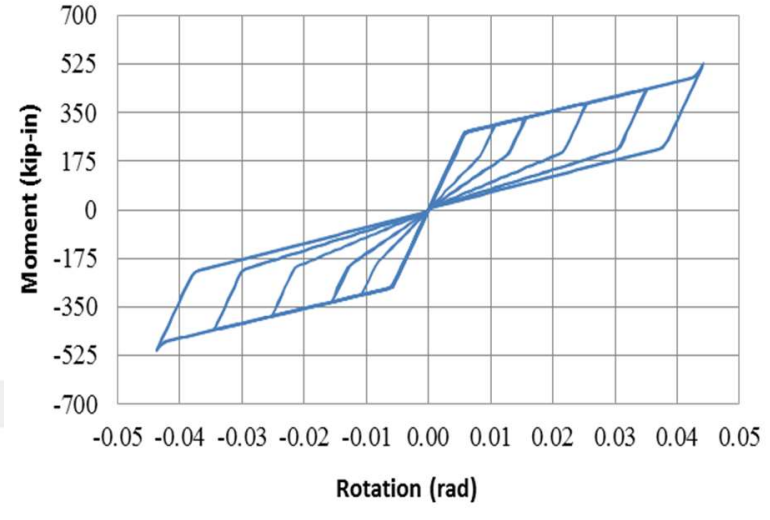

b) FE moment-rotation

Figure 7: Experimental and simulated moment rotation behaviour of the superelastic SMA connection

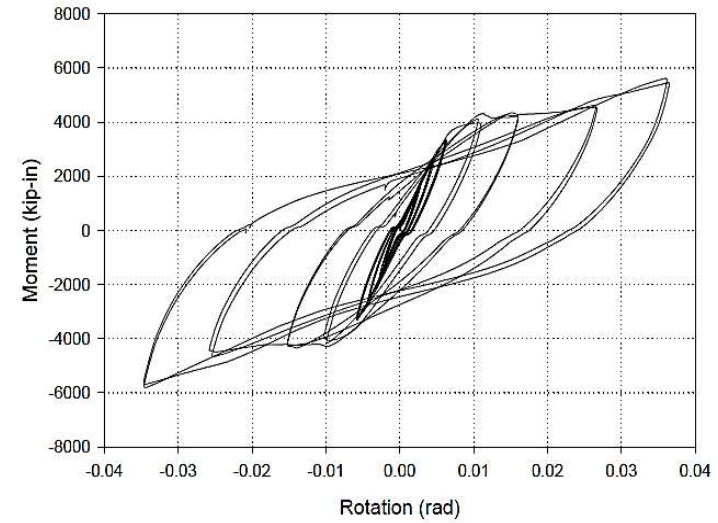

a) Experimental moment-rotation [8]

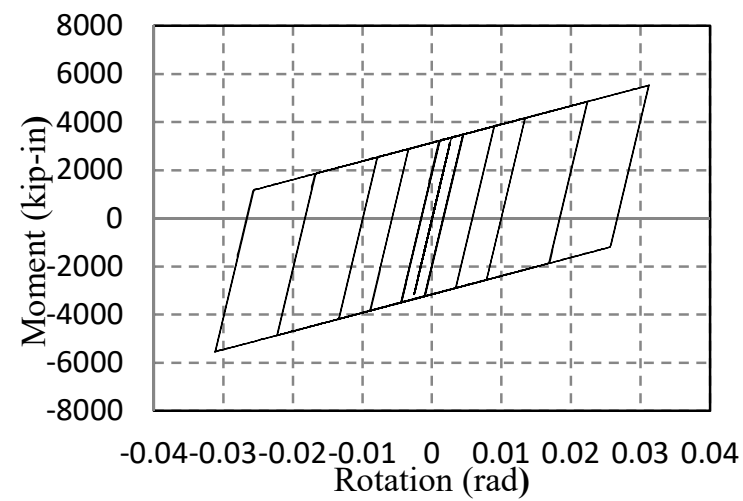

b) FE moment-rotation

Figure 8: Experimental and simulated moment rotation behaviour of martensite SMA connection

\subsection{DYNAMIC ANALYSIS OF SMA-STEEL FRAMES}

Eigen value analyses of the frames were first performed. Table 4 shows the natural periods of the frames. The location and number of SMA connections influenced the period. The first period of 
vibrations of the SMA frames increased by $1.8 \%$ to $26.2 \%$ as compared to the steel frame. Dynamic analyses of the SMA frames were then conducted considering the five selected earthquakes scaled to the intensity causing collapse of the steel frame (Frame 1).

The MIDs of the different frames are compared in Figure 9a. Frame 2 has the highest MID (3.48\% to $6.48 \%$ ). All of the other frames have relatively similar values ( $2.93 \%$ to $5.44 \%)$. Table 5 shows the percentage change of MID and MRID as compared with Frame 1. The maximum increase in MID (reaching 110\%), which was observed in Frame 2, signifies that using SMA in all of the frame connections is a solution that should be avoided. This increase in MID is related to the lower modulus of elasticity of the SMA as compared to steel. The minimum increase in MID was observed in Frame 6 (0.6\%).

The MRID values of different frames are compared in Figure 9(b). The highest reduction of the MRID occurs in Frame 2 for four out of the five considered ground motions (up to 90\%). For the fifth ground motion, the MRID increases as compared to Frame 1, which categorize the seismic behaviour of Frame 2 to below that of Frame 1. Although the same numbers of SMA connections were used in Frames 4, 5 and 6, Frame 4 shows better performance in terms of MRID as shown in the Table 5. The location of the SMA connections has significantly influenced the location of the storey experiencing the MID and MRID because the SMA connections have resulted in redistributing the seismic forces in the frame. The ID and RID distributions due to imperial earthquake (Figure 10) are discussed in the following paragraph. The remaining ID and RID distributions are given in Appendix A. The use of SMA connections has significantly reduced the RID for the first three floors of Frames 3 and 6. However, RID values for the remaining stories were not reduced. In case of Frames 4 and 5, the SMA connections have minimized the RID in all floors. 
Table 4 Natural time period of different frames (Seconds)

\begin{tabular}{|c|c|c|c|c|c|c|c|}
\hline Time period & Frame 1 & Frame 2 & Frame 3 & Frame 4 & Frame 5 & Frame 6 & Frame 7 \\
\hline $\mathrm{T} 1$ & 2.21 & 2.79 & 2.25 & 2.34 & 2.32 & 2.27 & 2.33 \\
\hline $\mathrm{T} 2$ & 0.78 & 0.94 & 0.79 & 0.79 & 0.80 & 0.81 & 0.81 \\
\hline
\end{tabular}

Table 5 Percentage change of MID and MRID of SMA frames

\begin{tabular}{|c|c|c|c|c|c|c|c|c|c|c|}
\hline & \multicolumn{2}{|c|}{ Imperial } & \multicolumn{2}{c|}{ Northridge } & \multicolumn{2}{c|}{ Loma } & \multicolumn{2}{c|}{ San Fernando } & \multicolumn{2}{c|}{ Tabas } \\
\cline { 2 - 11 } & $\begin{array}{c}\text { MID } \\
\text { change }\end{array}$ & $\begin{array}{c}\text { MRID } \\
\%\end{array}$ change & $\begin{array}{c}\text { MID } \\
\text { change }\end{array}$ & MRID & $\begin{array}{c}\text { MID } \\
\% \text { change }\end{array}$ & MRID & $\begin{array}{c}\text { MID } \\
\text { change }\end{array}$ & MRID & $\begin{array}{c}\text { MID } \\
\text { change }\end{array}$ & $\begin{array}{c}\text { MRID } \\
\% \text { change }\end{array}$ \\
\hline Frame 2 & 56.9 & -74.7 & 9.78 & -76.4 & 29.1 & 19.5 & 18.4 & -90.3 & 110 & -74.4 \\
\hline Frame 3 & 16.5 & -8.77 & 5.27 & -44.6 & 1.31 & -24.7 & -3.16 & -3.31 & 6.55 & -43.2 \\
\hline Frame 4 & 23.1 & -45.3 & 4.73 & 7.07 & 7.17 & -42.9 & 2.01 & -40.50 & 21.8 & -8.50 \\
\hline Frame 5 & 18.5 & -45.3 & 5.14 & -25.4 & 8.43 & -30.2 & 6.90 & -21.24 & 6.91 & 3.06 \\
\hline Frame 6 & 16.8 & -0.590 & 6.62 & -34.2 & 0.60 & -40.7 & -2.01 & 0.00 & 9.93 & -21.8 \\
\hline Frame 7 & 22.2 & -37.8 & 5.50 & -35.1 & 4.96 & -47.6 & 1.28 & -28.52 & 13.7 & 1.61 \\
\hline
\end{tabular}

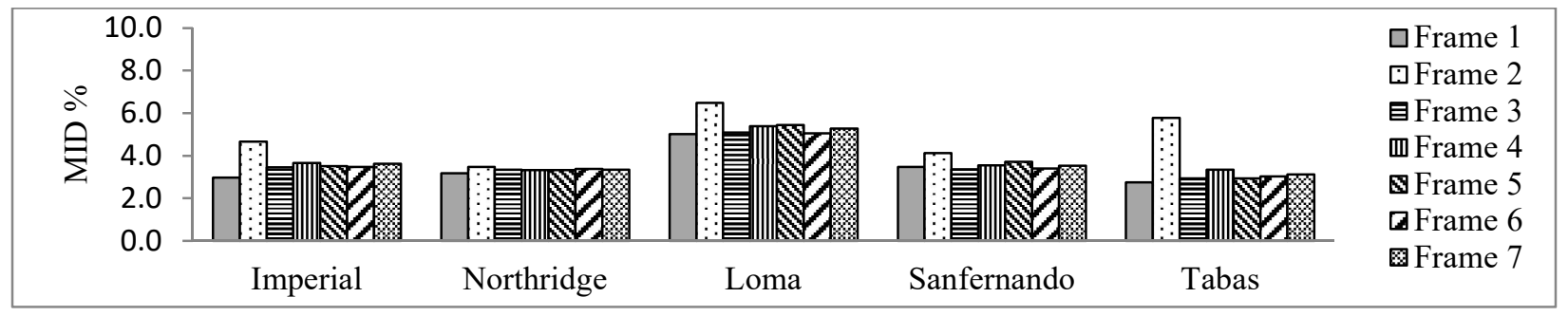

a) MID of different frames

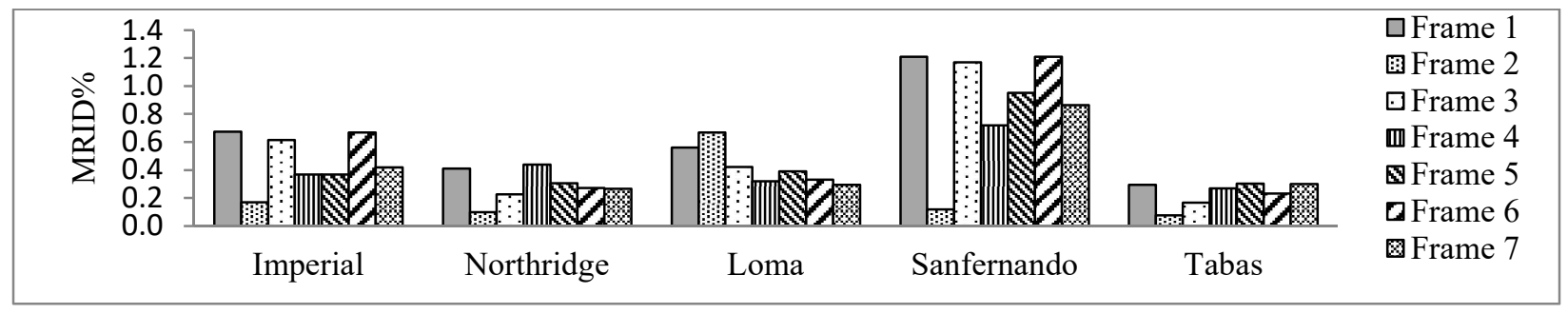

b) MRID of different frames

Figure 9: Comparison of MID and MRID of different frames 

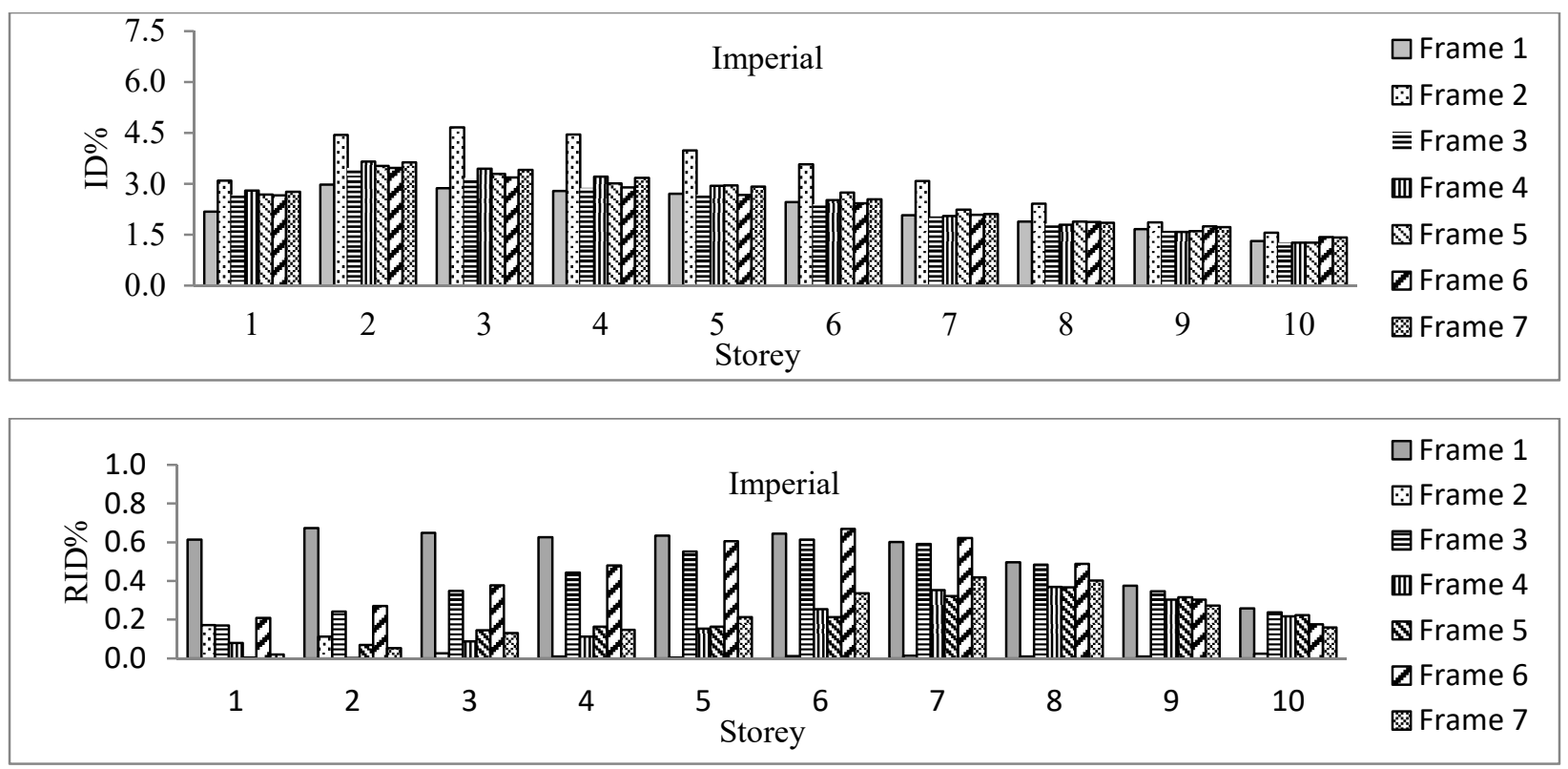

Figure 10: Imperial earthquake [Sa(T1,5\%)=0.341g]

The damage schemes of the six SMA frames are presented in Figures 11 to 16. Yielding is observed at the ends of almost all of the beams for the selected records. Yielding also observed at the midspan of the beams of top floors in case of Loma record.

The damage scheme of Frame 2 (Figure 11) shows that the first and the second storey columns yielded in cases of Imperial and Tabas records, only the first storey columns yielded due to San Fernando records. Yielding of columns of other stories also observed due to Loma, Northridge and Tabas records. For Northridge and San Fernando records, Frame 2 has not reached failure. The worst damage distribution was observed due to Imperial, Loma and Tabas earthquakes as three or four columns failed, respectively.

In case of Frame 3, the first floor columns yielded due to Imperial, Northridge, San Fernando, and Tabas earthquakes (Figure 12). In case of Loma record, yielding of the columns was observed at 
multiple storeys and two of the $1^{\text {st }}$ storey columns failed. Three columns of the $1^{\text {st }}$ storey failed due to imperial record, two columns failed due to Northridge records, and one column failed due to San Fernando and Tabas records.

Using SMA connections at both the $1^{\text {st }}$ and the $4^{\text {th }}$ floor (Frame 4 ) reduces the yielding of the beams at these floors as shown in Figure 13. Yielding is only observed in the first floor columns due to imperial and Tabas earthquakes. Column yielding is also observed at $5^{\text {th }}$ and $8^{\text {th }}$ stories considering Northridge record, $8^{\text {th }}$ storey considering San Fernando record and almost all storeys considering Loma record. Three and two columns of the $1^{\text {st }}$ floor failed due to imperial and Loma records, respectively, whereas only one column failed due to Northridge, San Fernando and Tabas records.

The damage schemes for Frame 5 (Figure 14), using SMA connections at the $1^{\text {st }}$ and $5^{\text {th }}$ storey show that three columns of $1^{\text {st }}$ floor failed due to Imperial and Northridge records whereas only one column failed due to Loma, San Fernando and Tabas records.

Although the same number of SMA connections is used in Frames 4, 5 and 6, Frame 6 is severely damaged compared with others as shown in the Figure 15. All columns of the first storey failed considering Loma earthquake, whereas three of the first storey columns failed due to imperial, Northridge, and San Fernando earthquakes.

The damage schemes of Frame 7 (Figure 16), using SMA connections at $1^{\text {st }}, 4^{\text {th }}$ and $9^{\text {th }}$ storeys, shows that the first storey is severely damaged due to imperial and San Fernando records as three columns failed. 
From the above discussions about drift values and damage schemes, it is clear that Frame 4 shows the best seismic performance as it has the best damage scheme, a minor increase in MID demands and high reduction of MRID compared with the other SMA-steel frames. The performance of Frame 4 as compared with the steel rigid frame (Frame 1) can be summarized in terms of MID and MRID. The average MID (3.85\%) of Frame 4 increases by only $10.7 \%$, whereas the average MRID $(0.42 \%)$ decreases by $32 \%$. The first storey of both frames was severely damaged. 


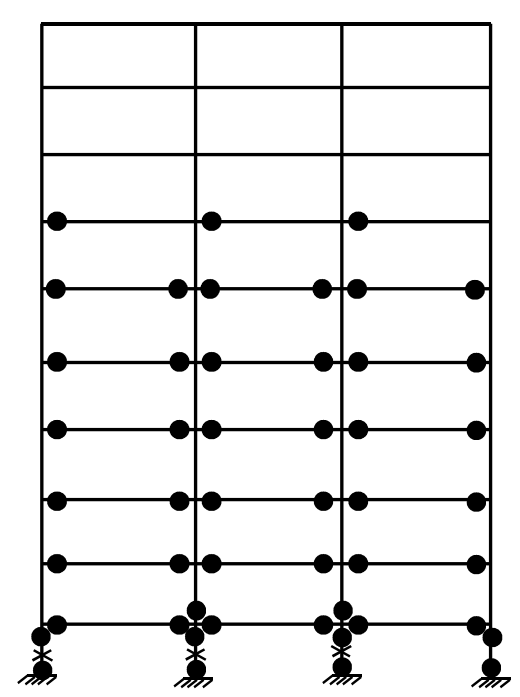

Imperial $[\mathrm{Sa}(\mathrm{T} 1,5 \%)=0.341 \mathrm{~g}]$

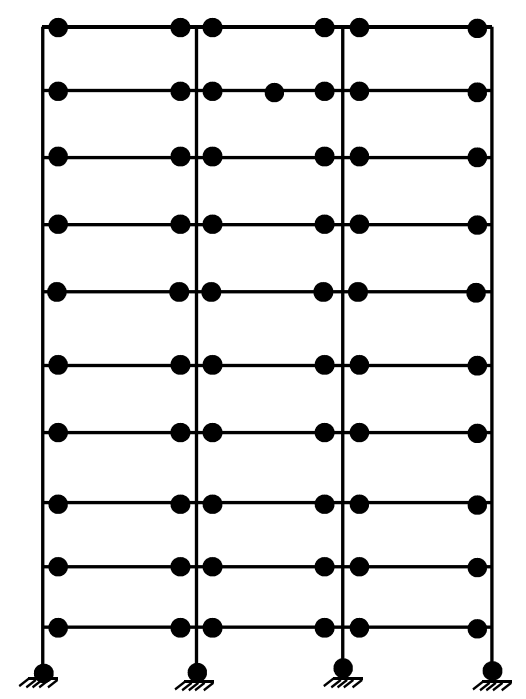

San Fernando $[\mathrm{Sa}(\mathrm{T} 1,5 \%)=0.476 \mathrm{~g}]$

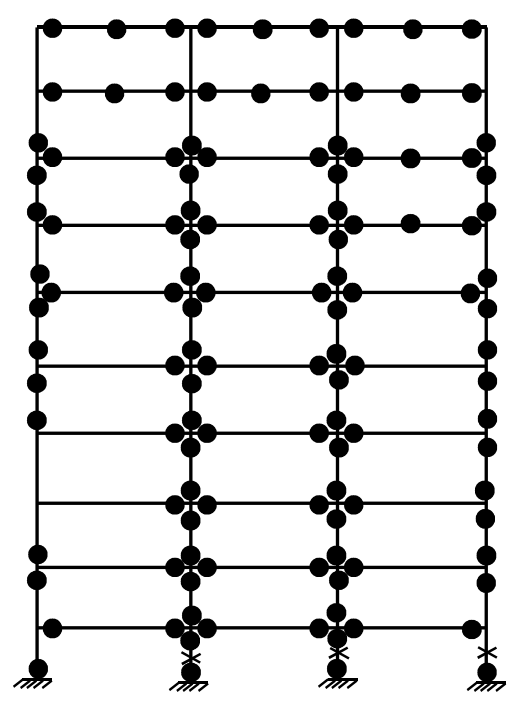

Loma $[\mathrm{Sa}(\mathrm{T} 1,5 \%)=0.619 \mathrm{~g}]$

Yield strain

$\times$ Ultimate rotation

Figure 11: Damage distribution of the Frame 2

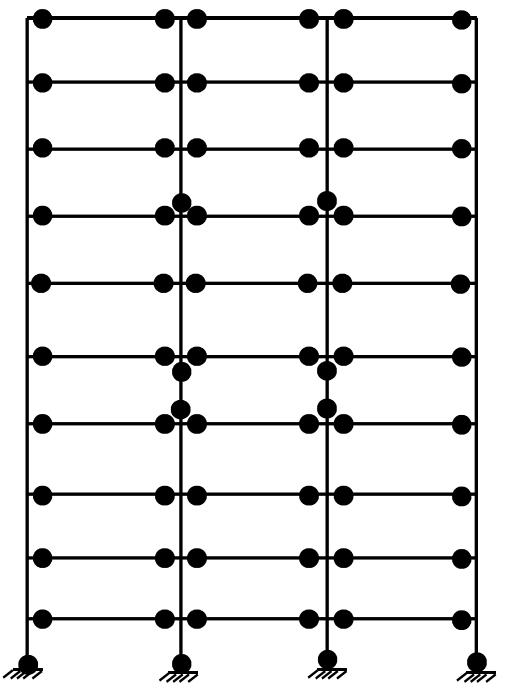

Northridge $[\mathrm{Sa}(\mathrm{T} 1,5 \%)=0.489 \mathrm{~g}]$

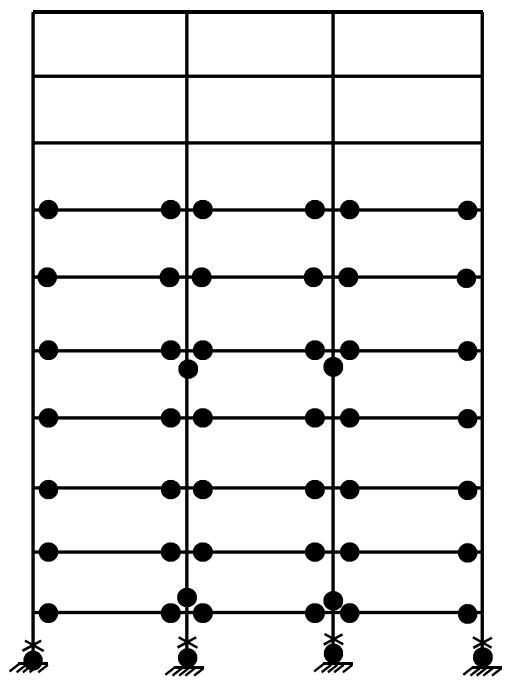

Tabas $[\mathrm{Sa}(\mathrm{T} 1,5 \%)=0.445 \mathrm{~g}]$ 


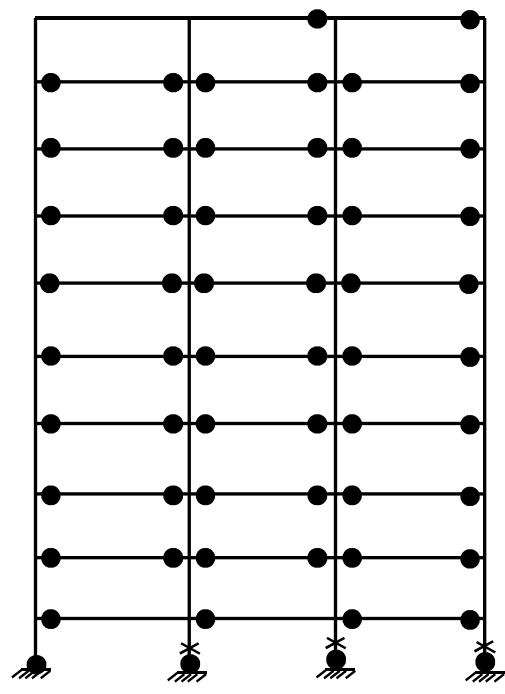

Imperial $[\mathrm{Sa}(\mathrm{T} 1,5 \%)=0.341 \mathrm{~g}]$

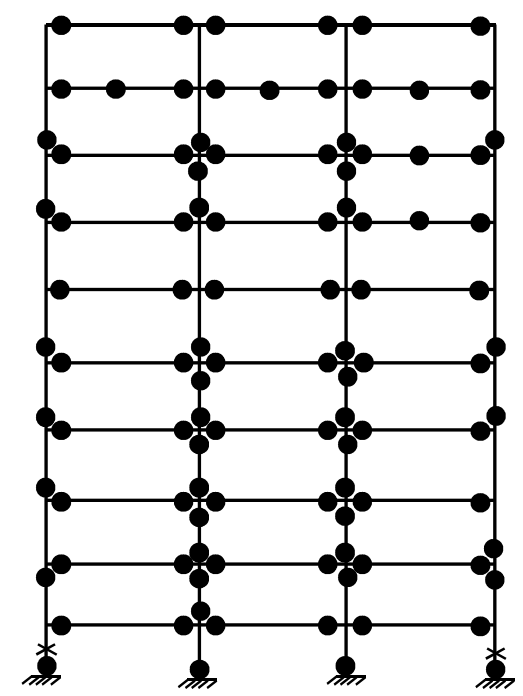

Loma $[\mathrm{Sa}(\mathrm{T} 1,5 \%)=0.619 \mathrm{~g}]$

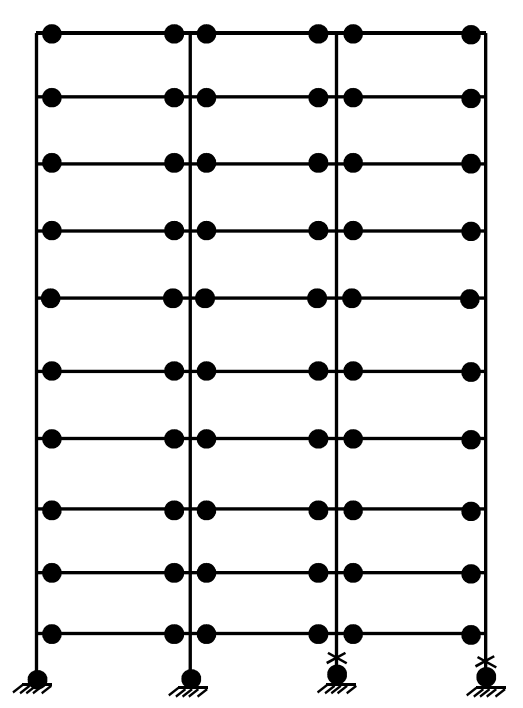

Northridge $[\mathrm{Sa}(\mathrm{T} 1,5 \%)=0.489 \mathrm{~g}]$

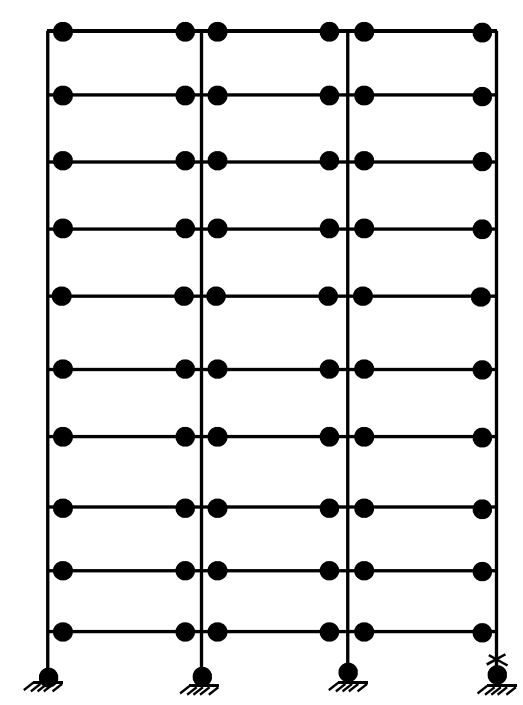

Tabas $[\mathrm{Sa}(\mathrm{T} 1,5 \%)=0.445 \mathrm{~g}]$
San Fernando $[\mathrm{Sa}(\mathrm{T} 1,5 \%)=0.476 \mathrm{~g}]$

- Yield strain

$\times$ Ultimate rotation

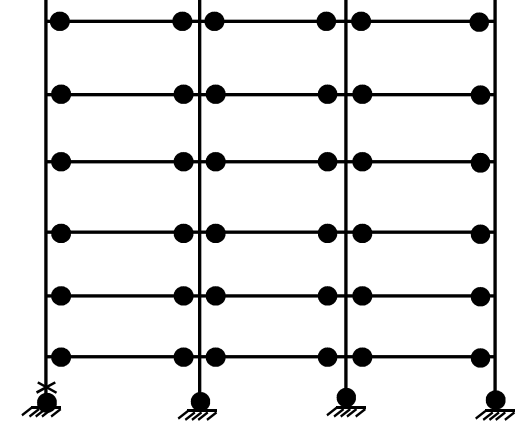

Figure 12: Damage distribution of the Frame 3 


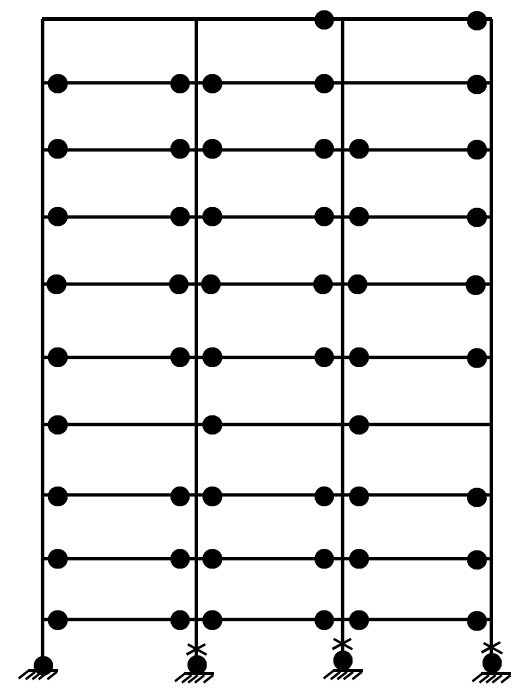

Imperial $[\mathrm{Sa}(\mathrm{T} 1,5 \%)=0.341 \mathrm{~g}]$

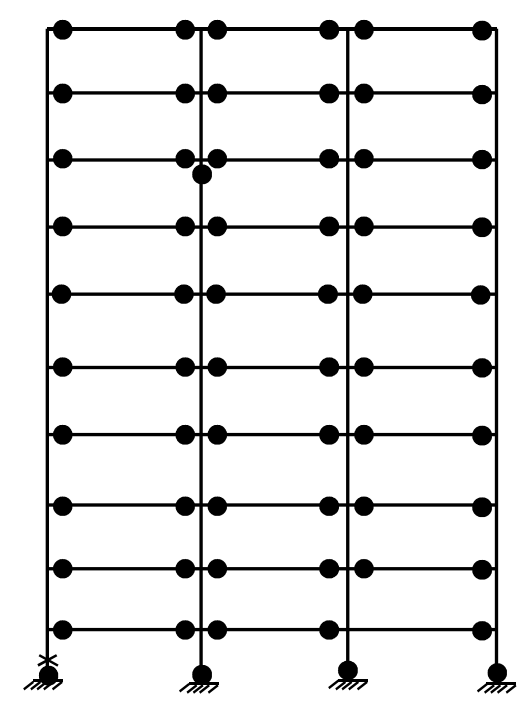

San Fernando $[\mathrm{Sa}(\mathrm{T} 1,5 \%)=0.476 \mathrm{~g}]$

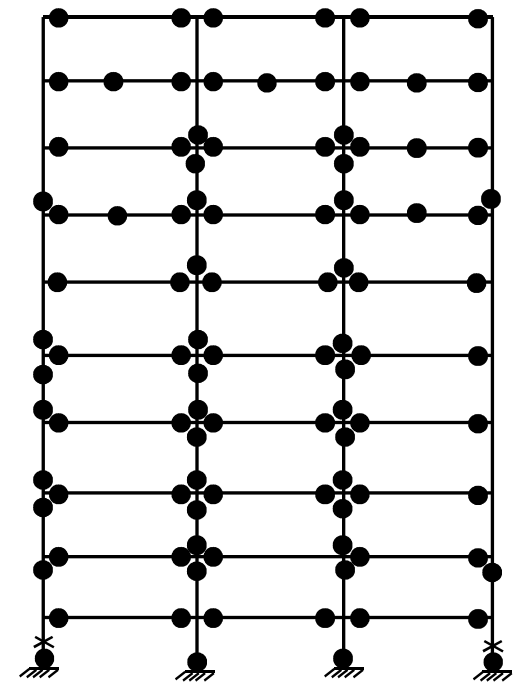

Loma $[\mathrm{Sa}(\mathrm{T} 1,5 \%)=0.619 \mathrm{~g}]$

- Yield strain

$X$ Ultimate rotation

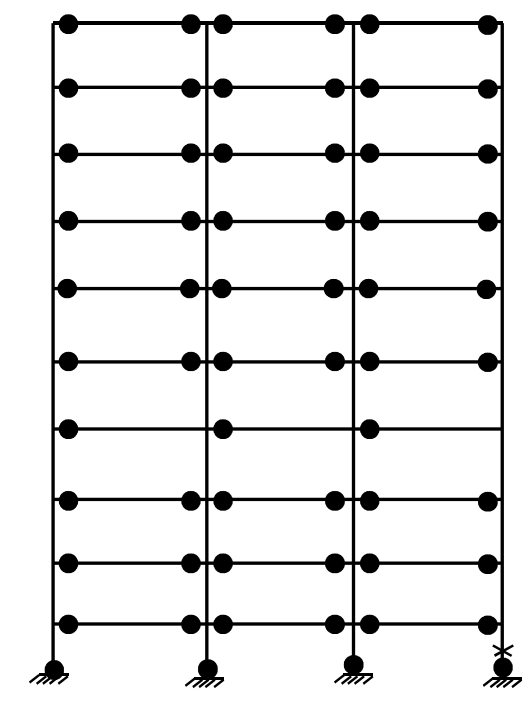

Tabas $[\mathrm{Sa}(\mathrm{T} 1,5 \%)=0.445 \mathrm{~g}]$

Figure 13: Damage distribution of the Frame 4 


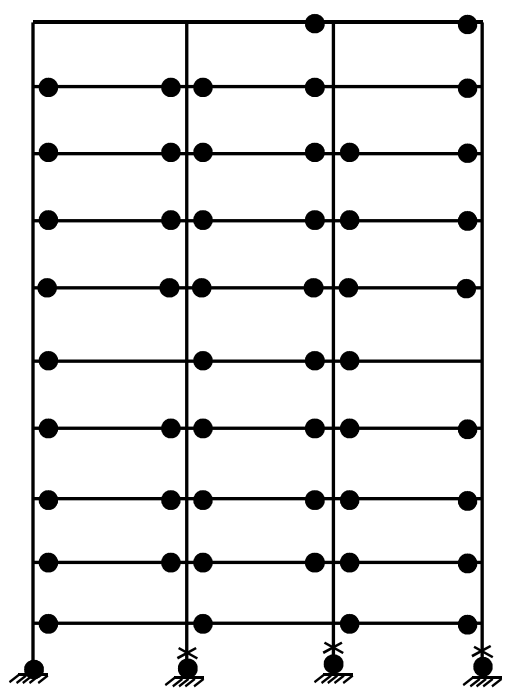

Imperial $[\mathrm{Sa}(\mathrm{T} 1,5 \%)=0.341 \mathrm{~g}]$

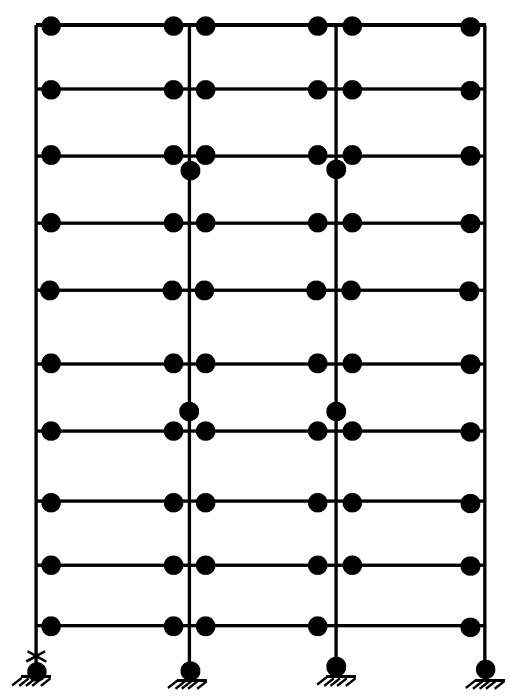

San Fernando $[\mathrm{Sa}(\mathrm{T} 1,5 \%)=0.476 \mathrm{~g}]$

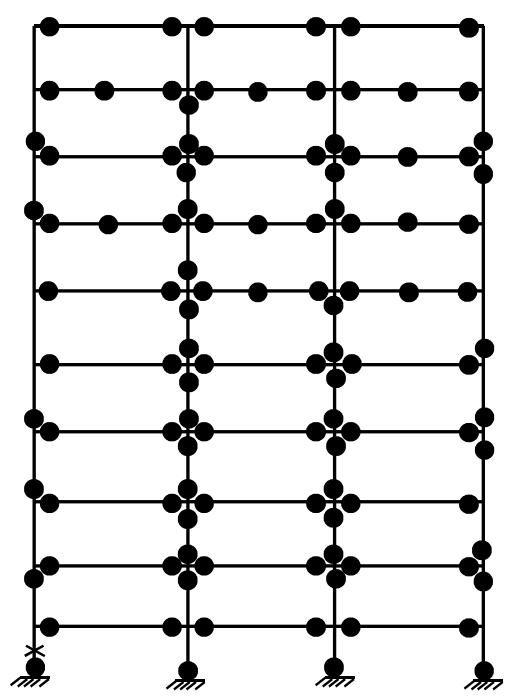

Loma $[\mathrm{Sa}(\mathrm{T} 1,5 \%)=0.619 \mathrm{~g}]$

Yield strain

$\times$ Ultimate rotation

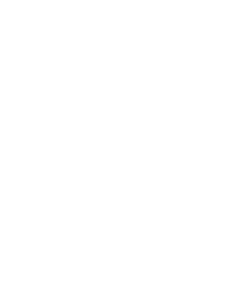




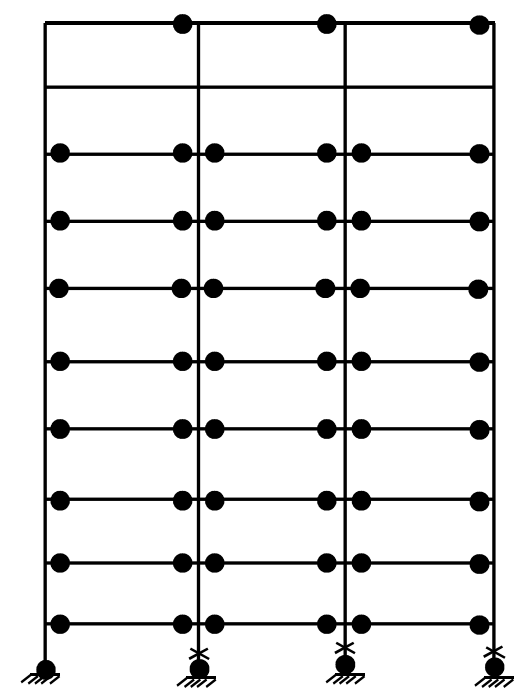

Imperial $[\mathrm{Sa}(\mathrm{T} 1,5 \%)=0.341 \mathrm{~g}]$

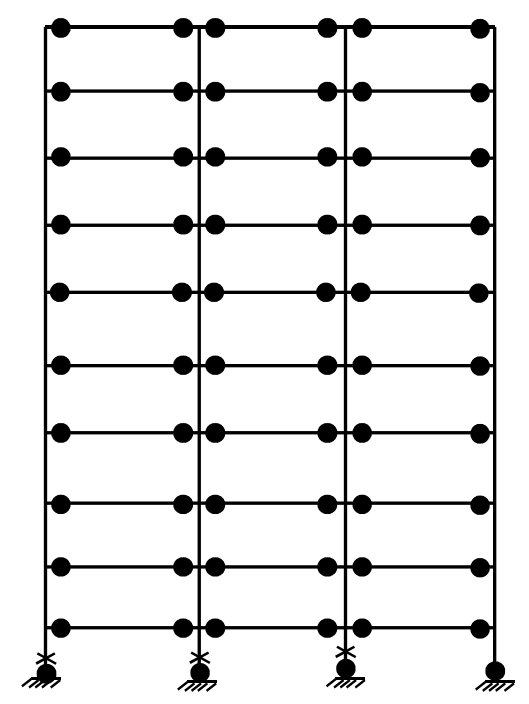

San Fernando $[\mathrm{Sa}(\mathrm{T} 1,5 \%)=0.476 \mathrm{~g}]$

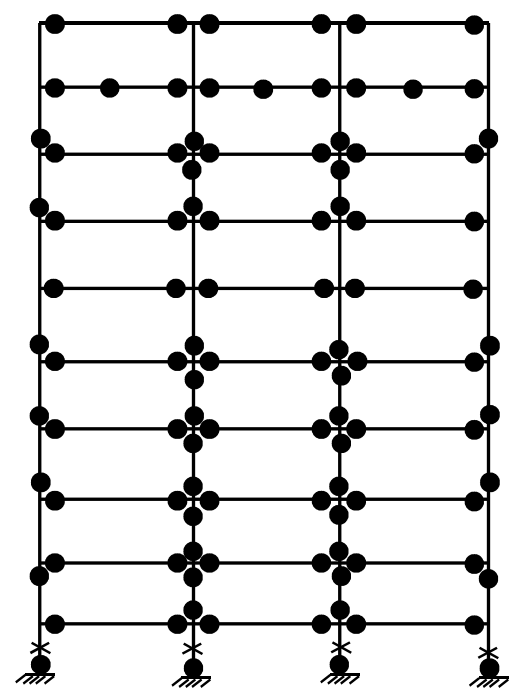

Loma $[\mathrm{Sa}(\mathrm{T} 1,5 \%)=0.619 \mathrm{~g}]$

Yield strain

$X$ Ultimate rotation

Figure 15: Damage distribution of the Frame 6

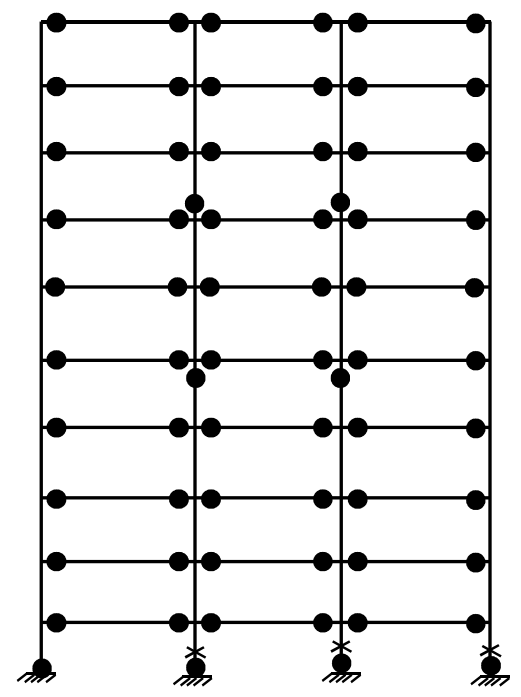

Northridge $[\mathrm{Sa}(\mathrm{T} 1,5 \%)=0.489 \mathrm{~g}]$

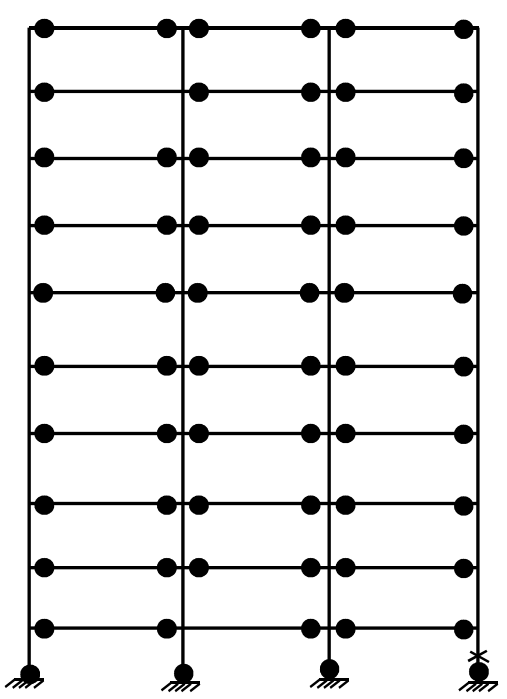

Tabas $[\mathrm{Sa}(\mathrm{T} 1,5 \%)=0.445 \mathrm{~g}]$ 


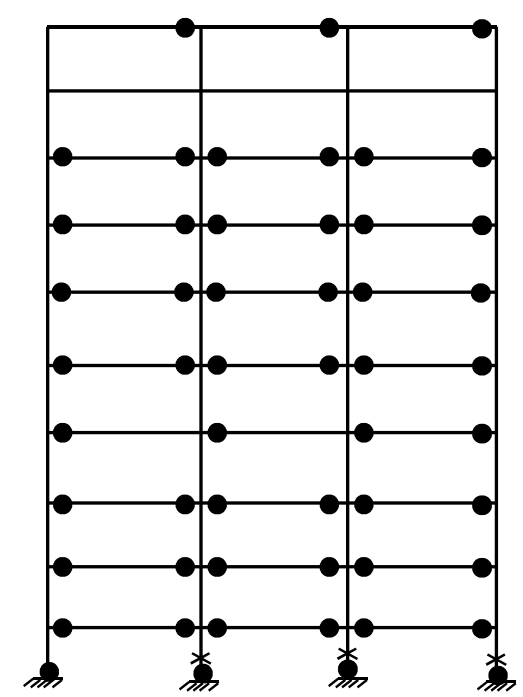

Imperial $[\mathrm{Sa}(\mathrm{T} 1,5 \%)=0.341 \mathrm{~g}]$

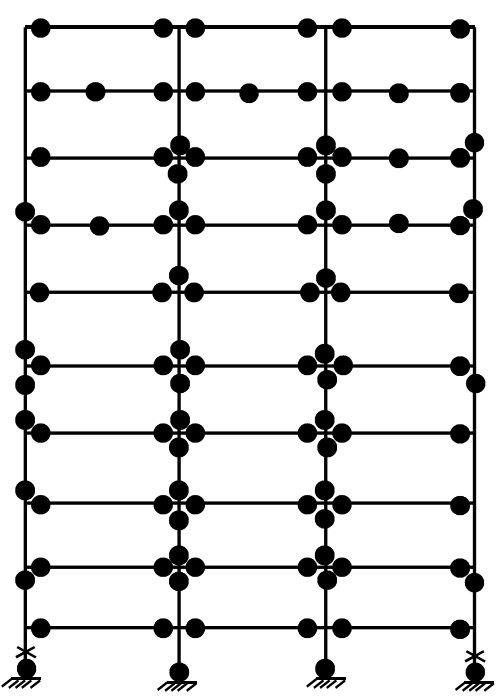

Loma $[\mathrm{Sa}(\mathrm{T} 1,5 \%)=0.619 \mathrm{~g}]$

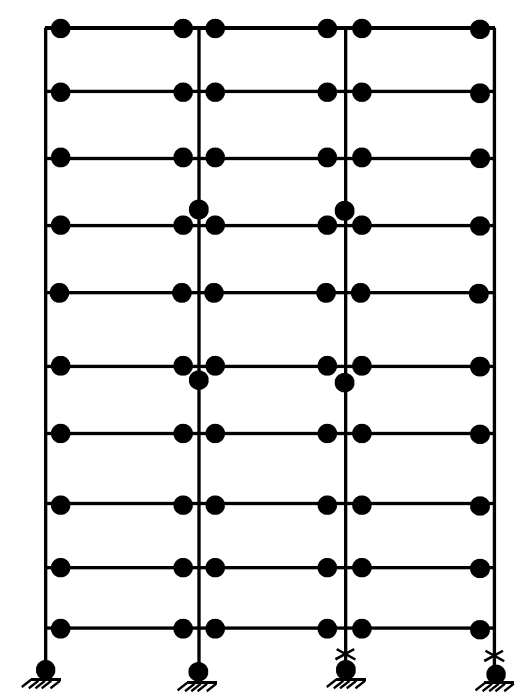

Northridge $[\mathrm{Sa}(\mathrm{T} 1,5 \%)=0.489 \mathrm{~g}$ ]

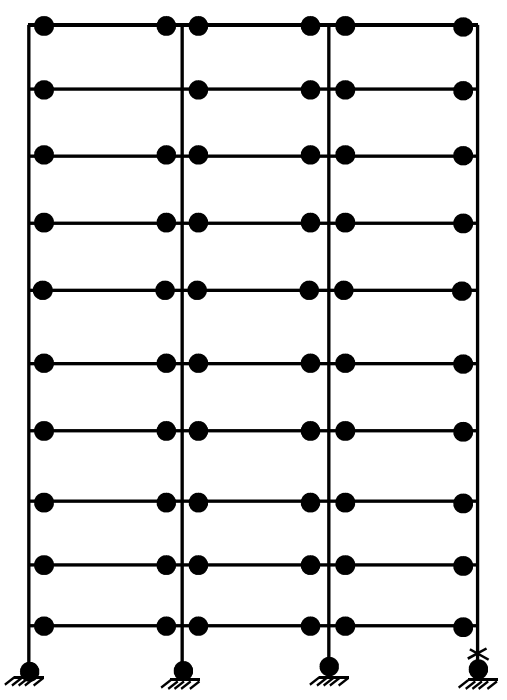

Tabas $[\mathrm{Sa}(\mathrm{T} 1,5 \%)=0.445 \mathrm{~g}]$

San Fernando $[\mathrm{Sa}(\mathrm{T} 1,5 \%)=0.476 \mathrm{~g}]$

Yield strain

$X$ Ultimate rotation

Figure 16: Damage distribution of the Frame 7

\subsection{CONCLUSION}

The seismic performance of SMRFs using SMA connections at certain locations is investigated in this paper in terms of MID, MRID and damage scheme. The modeling technique of SMA 
connections is validated using the experimental results available in literature. A ten storey building is considered as a case study. IDA analysis is conducted using five different ground motions scaled to different Sa levels up to Collapse. After that rigid connections are replaced by the SMA connections. Nonlinear dynamic analyses of six different SMA frames are conducted using the same records scaled to the predefined Sa level that caused collapse of the steel frame. The seismic performance of the steel frame is compared with the SMA frames in terms of MID, MRID and damage schemes.

- The MID is influenced by the number of SMA connections used whereas the MRID is affected by the location of the SMA connections.

- Replacing all the rigid connections by SMA connections significantly increased MID (up to $110 \%$ ), and, thus the frame was severely damaged for three records compared with the steel frame.

- Among all SMA frames, Frame 4 (using SMA connections at the critical first floor and fourth floor) showed very good seismic performance compared with the steel frames in terms of MID, MRID and damage schemes. The MID increased by $23 \%$ and the MRID reduced by $45 \%$.

- Using SMA connections at the joints located at the top and/or bottom of the critical columns identified by the simplified method will lead to the best seismic performance.

- The seismic performance of the SMRFs can be improved by using SMA connections at chosen locations, which will lead to minor increase in MID, high reduction in MRID, and lower level of damage distribution. 


\section{REFERENCES}

[1] CAN/CSA-S16-09, Design of Steel Structures, Canadian Standard Association, 2009.

[2] AISC 341-02, Seismic Provisions for Structural Steel Buildings, American Institute of Steel Construction, 2002.

[3] FEMA 350, Recommended Seismic Design Criteria for New Steel Moment-Frame Buildings Federal Emergency Management Agency 2000.

[4] J.M. Ricles, R. Sause, M.M. Garlock, C. Zhao, Posttensioned seismic-resistant connections for steel frames, J. Struct. Eng. 127(2) (2001) 113-121.

[5] C. Christopoulos, A. Filiatrault, C. Uang, B. Folz, Posttensioned energy dissipating connections for moment-resisting steel frames, J. Struct. Eng. 128 (2002) 1111-1120.

[6] M.M. Garlock, J. M. Ricles, R. Sause, Experimental studies of full-scale posttensioned steel connection, J. Struct. Eng. 131 (2005) 438-448.

[7] J. McCormick, J. Tyber, R. DesRoches, k.Gall, H. Maier, Structural engineering with NiTi Part II: Mechanical behavior and scaling, J. Eng. Mech. 133(9) (2007) 1019-1029.

[8] J. Ocel, R. DesRoches, R.T. Leon, W.G. Hess, R. Krumme, J.R. Hayes, S. Sweeney, Steel beam-column connections using shape memory alloys, J. Struct. Eng. 130 (2004) 732-740.

[9] H. Ma, T. Wilkinson, C. Chongdu, Feasibility study on a self-centering beam-to-column connection by using the superelastic behavior of SMAs, Smart. Mater. Struct. 16 (2007) 15551563.

[10] H. Ma, and M. C. H. Yam, Experimental study on a beam-to-column connection using Shape Memory Alloy, Adv. Mater. Res. 374-377 (2012) 2176-2179.

[11] J. Sepúlveda, R. Boroschek, R. Herrera, O. Moroni, M. Sarrazin, Steel beam-column connection using copper-based shape memory alloy dampers, J. Constr. Steel Res. 64 (2008) 429-435.

[12] M.S. Speicher, R. DesRoches, R.T Leon, Experimental results of a NiTi shape memory alloy (SMA)-based recentering beam-column connection. Eng Struct. 33 (2011) 2448-2457.

[13] R. DesRoches, B. Taftali, B.R. Ellingwood, Seismic performance assessment of steel frames with shape memory alloy connections, Part I- Analysis and seismic demands, J. Earthq. Eng. 14 (2010) 471-486.

[14] B.R. Ellingwood, B. Taftali, R. Desroches, Seismic performance assessment of steel frames with shape memory alloy connections, Part II- Probabilistic demand assessment, J. Earthq. Eng. 14 (2010) 631-645.

[15] Y.L.Han, Q.S.Li, A.Q. Li, A.Y.T Leung, P.H. Lin, Structural vibration control by shape memory alloy damper, Earthq Eng Struct D, 32 (2003) 483-494.

[16] M. Dolce, D.Cardone, R. Marnetto, M. Mucciarelli, D. Nigro, F.C. Ponzo, G. Santarsiero, Experimental static and dynamic response of a real R/C frame upgraded with SMA recentering and dissipating braces, Proc. $13^{\text {th }}$ World Conference on Earthquake Engineering, Vancouver, Canada, 2004, (paper no. 2878).

[17] J. McCormick, R. DesRoches, D. Fugazza, F. Auricchio, Seismic assesment of concentrically braced steel frames with shape memory alloy braces", J. Struct. Eng. 133 (2007) 862-870.

[18] Shabelli, R., Mahin, S., and Chang, C. "Seismic demand on steel braced frame buildings with buckling-restrained braces", Eng. Struct. 25(5) (2003) 655-666.

[19] A. Kari, M. Ghassemieh, S.A. Abolmaali, A new dual bracing system for improving the seismic behavior of steel structures, Smart. Mater. Struct. 20 (12) (2011) 125020.

[20] A.D. Cesare, F.C. Ponzo, D. Nigro, M. Dolce, C. Moroni, Experimental and numerical behaviour of hysteretic and visco-recentring energy dissipating bracing systems, Bull Earthquake Engineering, 10(5) (2012) 1585-1607. 
[21] D.J Miller, Development and experimental validation of self-centering buckling-restrained braces with shape memory alloy, M.Sc thesis, University of Illinois at Urbana-Champaign, USA, 2011.

[22] P. Sultana, M.A. Youssef, Prediction of local seismic damage in steel moment resisting frames, J. Constr. Steel. Res. 122 (2016) 122-137.

[23] D. Ozhendekci, N. Ozhendekci, Seismic performance of steel special moment resisting frames with different span arrangements, J. Constr. Steel Res. 72 (2012) 51-60.

[24] ANSI/AISC 361-89. Manual of Steel Construction: Allowable stress design, American Institute of Steel Construction, 1989.

[25] SeismoStruct (version 6) - A computer program for static and dynamic nonlinear analysis of framed structures. Available online from http://www.seismosoft.com.

[26] FEMA 356, Prestandard and Commentary for the Seismic Rehabilitation of Buildings, Federal Emergency Management Agency, 2000.

[27] N. Luco, C.A. Cornell, Effects of random connection fractures on the demands and reliability for a three-storey pre-Northridge (SMRP) structure. Proc. of the Sixth US National Conf. on Earthquake Eng., Earthquake Engineering Research Institute, Oakland, California, USA.

[28] PEER ground motion database, Pacific Earthquake Engineering Research Center, University of California, Berkeley, USA, 2013, http://ngawest2.berkeley.edu/.

[29] F. Auricchio, E. Sacco, A one-dimensional model for superelastic shape-memory alloys with different elastic properties between austenite and martensite, Int. J. Nonlin. Mech. 32 (1997) 1101-1114. 
Appendix A

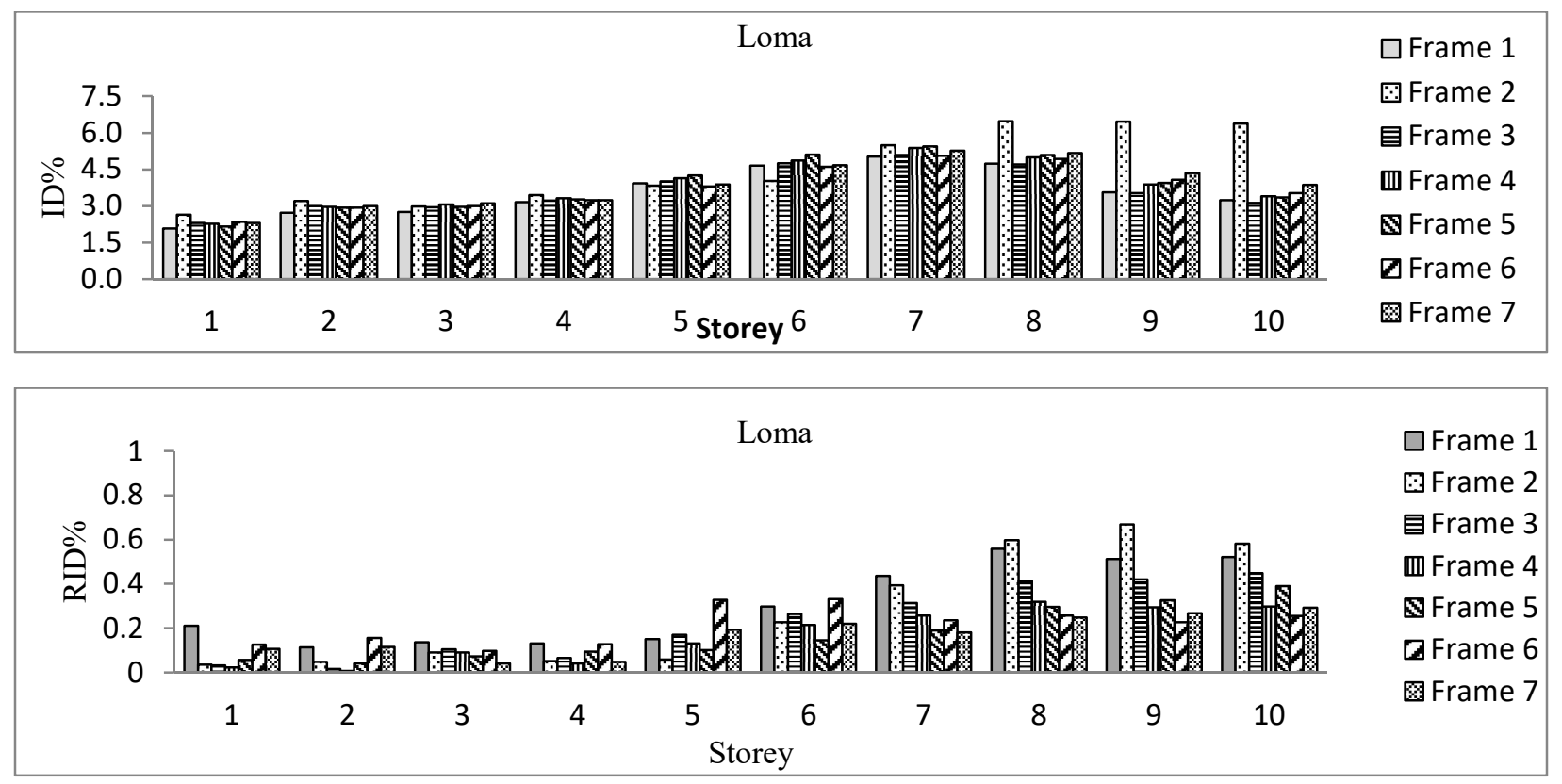

Figure 1: Loma earthquake

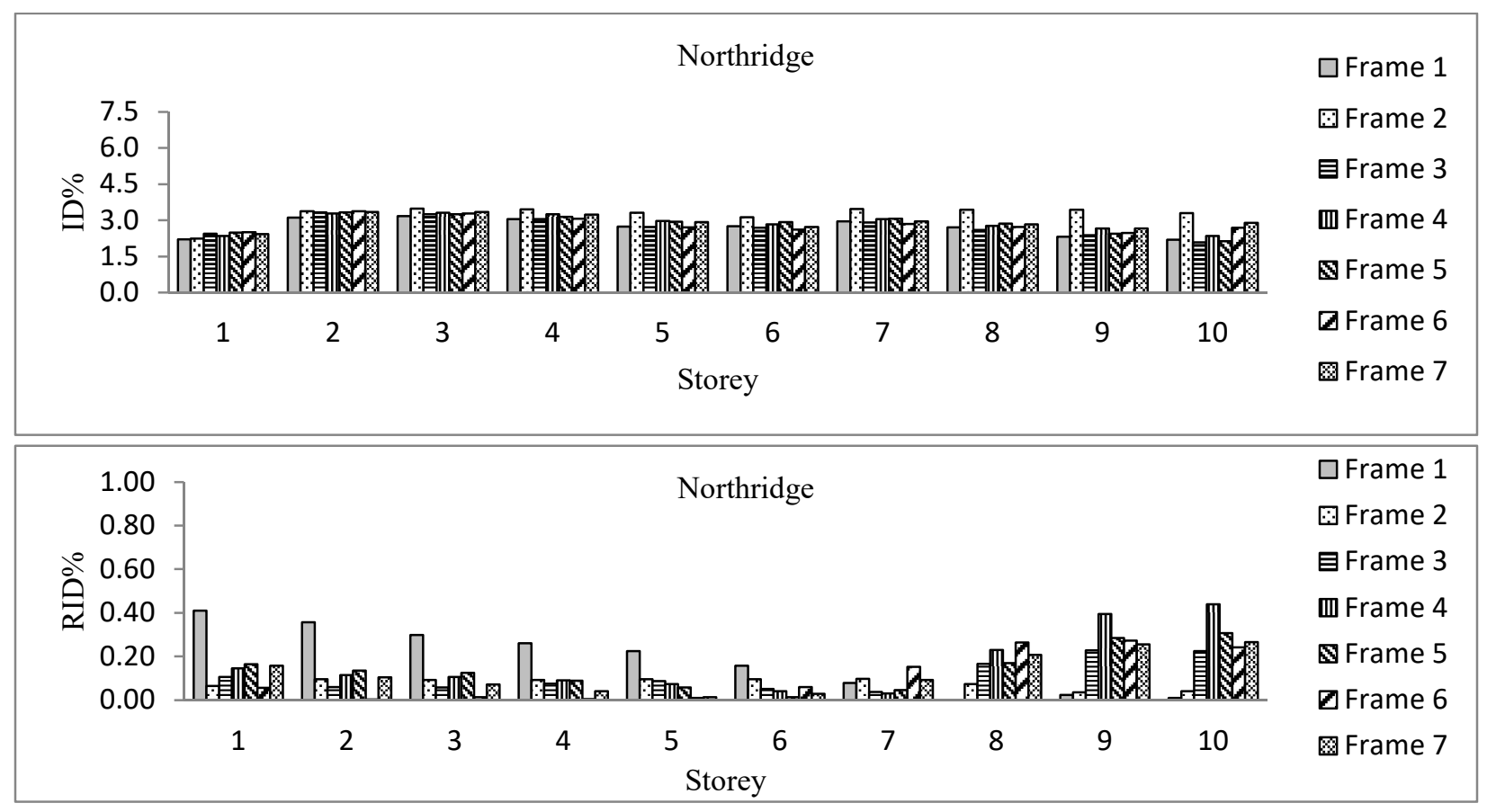

Figure 2: Northridge earthquake 

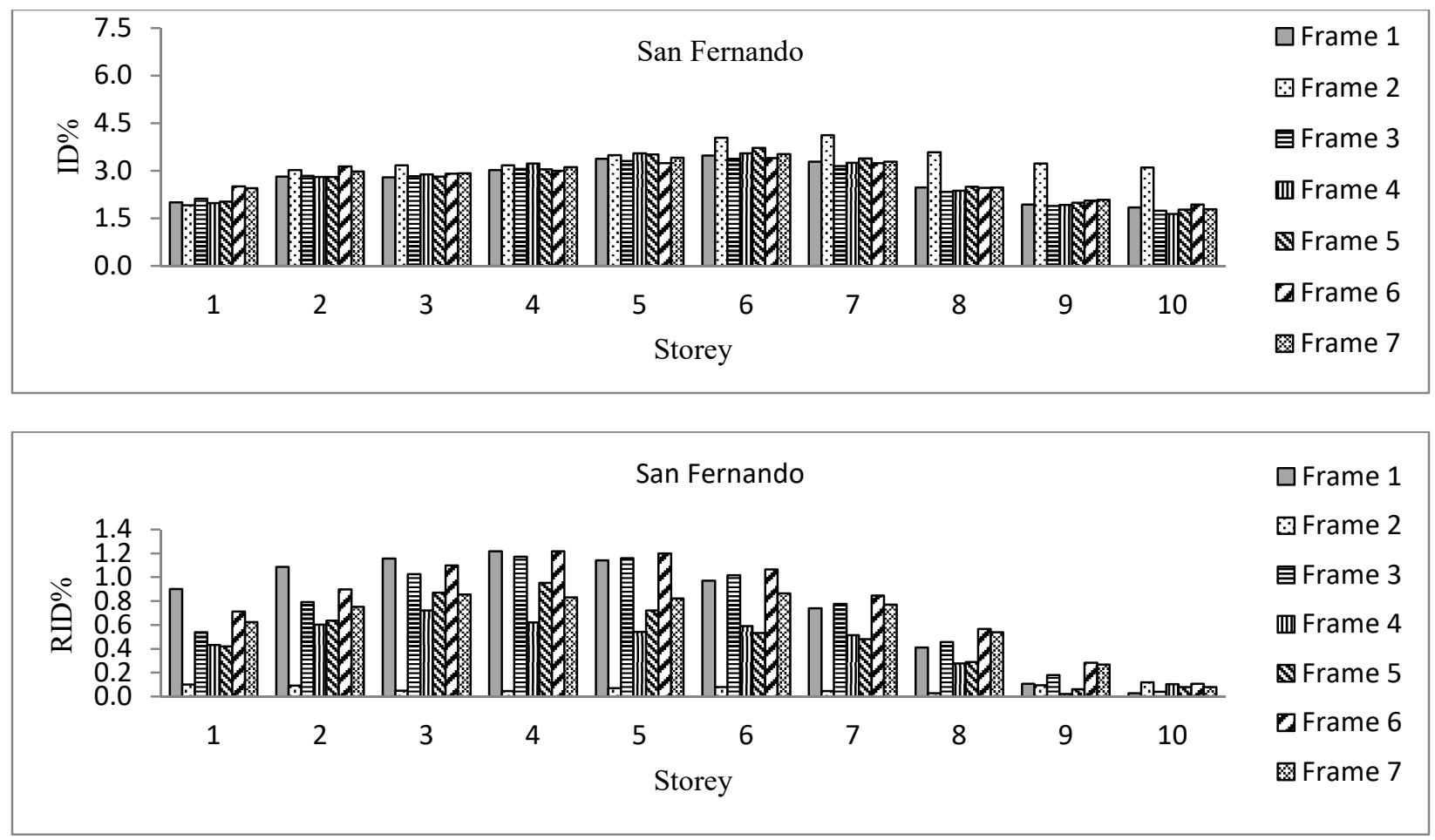

Figure 3: San Fernando earthquake
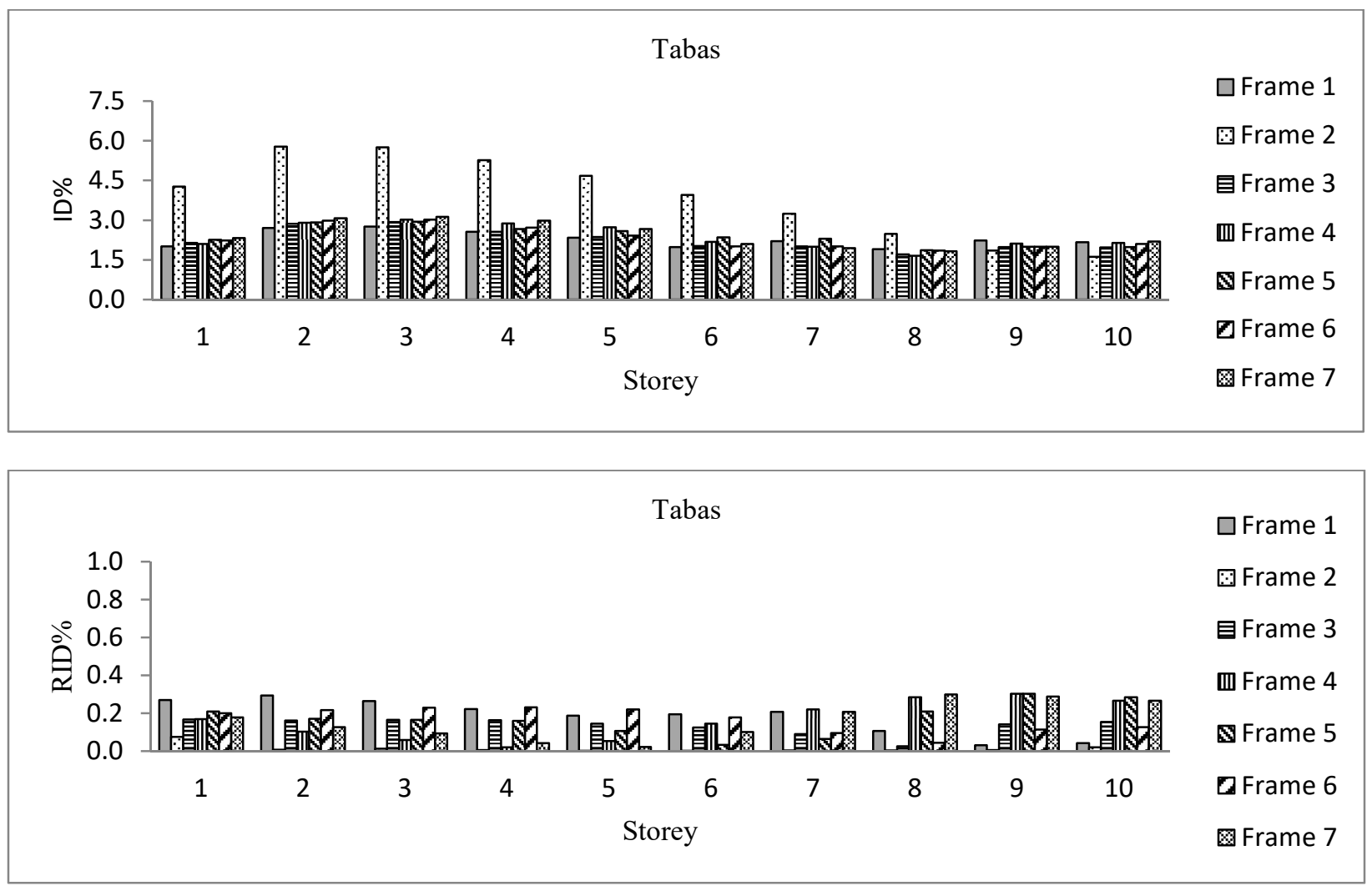

Figure 4 Tabas earthquake 